Technological University Dublin ARROW@TU Dublin

2015-07-13

\title{
Thermal Energy Storage in Building Integrated Thermal Systems: A Review. Part 2. Integration as Passive System
}

\author{
Dervilla Niall \\ Technological University Dublin, dervilla.niall@tudublin.ie \\ Sarah McCormack \\ Trinity College Dublin, mmcorms@tcd.ie \\ Philip Griffiths \\ University of Ulster
}

See next page for additional authors

Follow this and additional works at: https://arrow.tudublin.ie/engineducart

Part of the Architectural Engineering Commons, Civil Engineering Commons, Other Engineering Commons, and the Structural Engineering Commons

\section{Recommended Citation}

Niall, D. et al. (2015) Thermal Energy Storage in Building Integrated Thermal Systems: A Review. Part 2. Integration as Passive System, Journal Renewable Energy, vol. 85, January 2016 pp. 1334-1356. doi:10.1016/j.renene.2015.06.064

This Article is brought to you for free and open access by the Engineering: Education and Innovation at ARROW@TU Dublin. It has been accepted for inclusion in Articles by an authorized administrator of ARROW@TU Dublin. For more information, please contact arrow.admin@tudublin.ie, aisling.coyne@tudublin.ie, gerard.connolly@tudublin.ie.

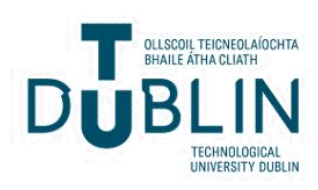




\section{Authors}

Dervilla Niall, Sarah McCormack, Philip Griffiths, Luisa Cabeza, Lidia Navarro, Albert Castell, Alvaro de Grazia, and Maria Brown 


\section{Authors}

Dervilla P. Niall CEng, Sarah McCormack Dr, Philip Griffiths Dr, Luisa F. Cabeza Dr, Lidia Navarro, Albert Castell, Alvaro de Grazia, and Maria Brown 
Review

\title{
Thermal energy storage in building integrated thermal systems: A review. Part 2. Integration as passive system
}

\author{
Lidia Navarro a, Alvaro de Gracia ${ }^{b}$, Dervilla Niall ${ }^{c}$, Albert Castell a, Maria Browne ${ }^{\text {c }}$ \\ Sarah J. McCormack ${ }^{c}$, Philip Griffiths ${ }^{\mathrm{d}}$, Luisa F. Cabeza ${ }^{\mathrm{a}, *}$ \\ ${ }^{a}$ GREA Innovació Concurrent, Universitat de Lleida, Edifici CREA, Pere de Cabrera s/n, 25001 Lleida, Spain \\ ${ }^{\mathrm{b}}$ CELIMIN, Universidad de Antofagasta, Av. Universidad de Antofagasta 02800, Antofagasta, Chile \\ ${ }^{\mathrm{c}}$ Department of Civil, Structural and Environmental Engineering, University of Dublin, Trinity College, Dublin, Ireland \\ d Centre for Sustainable Technologies, University of Ulster at Jordanstown, Newtownabbey, Co. Antrim BT38 9QB, UK
}

\section{A R T I C L E I N F O}

\section{Article history:}

Received 19 February 2015

Received in revised form

10 June 2015

Accepted 26 June 2015

Available online $\mathrm{xxx}$

\section{Keywords:}

Thermal energy storage

Passive system

Building integrated

Sensible heat storage

Latent heat storage

\begin{abstract}
A B S T R A C T
Energy consumption trends in residential and commercial buildings show a significant increase in recent decades. One of the key points for reducing energy consumption in buildings is to decrease the energy demand. Buildings envelopes are not just a structure they also provide protection from outdoor weather conditions always taking into account the local climate. Thermal energy storage has been used and applied to the building structure by taking advantage of sensible heat storage of materials with high thermal mass. But in recent years, researchers have focused their studies on the implementation of latent heat storage materials that if well incorporated could have high potential in energy demand reduction without occupying the space required by sensible storage. The aim of this study is to review the thermal energy storage passive systems that have been integrated in building components such as walls, ceilings or floors, and to classify them depending on their component integration.
\end{abstract}

() 2015 Elsevier Ltd. All rights reserved.

\section{Introduction}

Buildings use $32 \%$ of global final energy demand, and generate $30 \%$ of energy-related $\mathrm{CO}_{2}$ emissions, and approximately one-third of the black carbon emissions [1]. Over $60 \%$ of residential and almost $50 \%$ of commercial buildings use thermal energy, with higher contribution from water heating in residential buildings and from cooling in commercial ones.

The drivers of the heating and cooling energy demand in buildings were identified by Ürge-Vorsatz et al. [1] such as; number of households, persons per household, floor space per capita, and specific energy consumption; and for commercial buildings are GDP (gross domestic product), floor space per GDP, and specific energy consumption.

The trends in Fig. 1 show that decreasing the energy demand of buildings is a necessity. As shown in Part 1 of this review [2], TES (Thermal energy storage) is one of the highlighted technologies to achieve this aim, and its integration in buildings is of much interest,

\footnotetext{
* Corresponding author.

E-mail address: Icabeza@diei.udl.cat (L.F. Cabeza).
}

to achieve a better final user acceptance of the technology.

This part of the review presents building integrated passive thermal storage systems. As commented in Part 1 [2], although building integration is not mentioned in the publications classified here, these systems are integrated in the building per se, since they are included in the building core (usually in the walls, ceiling or floor). Active TES systems are presented in Part 1.

Of the three thermal energy storage methods existing, only sensible heat storage and latent heat storage are used in passive building systems. Thermochemical energy storage always uses active systems. The following section provides the classification of the storage methods.

\section{Sensible heat storage}

Sensible heat storage is the most common thermal storage method which has been used in several applications with water, stone, or brick as the storage material. The method consists of transferring heat to the storage medium that will increase its temperature and store that heat [3]. The potential of this method mainly depends on the heat capacity of the storage material, the mass and the thermal gradient to which the storage is exposed. 

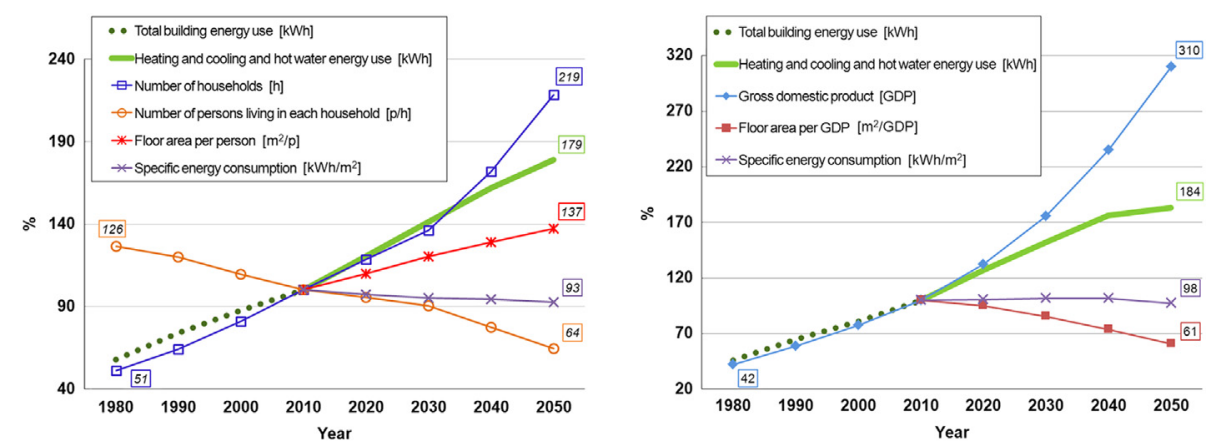

Fig. 1. Trends in the different drivers of energy consumption in residential (left) and commercial (right) buildings [1].

\subsection{High thermal mass materials}

High thermal mass materials are those that are able to store a high amount of heat and hence giving high thermal inertia to the building components. These properties, when included in a building, give thermal stability and smooth the thermal fluctuations between outside and inside conditions [4]. Most commonly used materials in buildings with high thermal inertia are stone, adobe, rammed earth, brick, water, and concrete.

Rempel and Rempel [5] did a very interesting comparison of different thermal mass systems (authors call them passive systems), comparing mainly rocks, clays, water and salts. The authors showed that while passive systems cannot provide the instant heating or cooling of a mechanical switch, they are nevertheless highly adjustable by variation of material, thickness, and configuration, and therefore can be refined to meet the occupant needs. Moreover, patterns of heat uptake, storage, and delivery vary in characteristic, reproducible ways with material and thickness, as illustrated in Fig. 2. This knowledge, if well implemented, allows builders, engineers and architects to be incorporated into the early stages of building designs. In addition, an intuitive understanding of thermal storage performance could be done depending on the final use of the building, hence each case should be considered independently (as presented in Fig. 3).

\subsubsection{Stone}

Looking at traditional building systems, thermal mass materials are found in several regions all over the world. Basaran et al. [6] measured temperatures and humidity of the typical Harran houses (built mainly out of brick and stone, mortared and plastered by mud) in the Anatolian region. In this study the solar chimney effect was also evaluated, together with the thermal mass of the construction materials used. The results showed that the indoor conditions were within the limits for thermal comfort even under extreme summer conditions.

On the other hand, recent research on the use of stone as high thermal mass material has focussed on experimental tests. For example, Ogoli [7] monitored four environmental test chambers with different thermal mass levels (natural stone, heavy concrete, timber panelling and lightweight galvanized corrugated iron sheets) in Nairobi, Kenya, during the warm period. Results showed that high thermal mass was very effective in lowering indoor maximum temperatures below the high outdoor maxima. On a hot day, when the maximum outdoor temperature was over $33^{\circ} \mathrm{C}$, the indoor maximum temperature in a high mass building was $25.4{ }^{\circ} \mathrm{C}$, which is within the comfort zone.

\subsubsection{Earth}

Earthen constructions have been used in many parts of the world as an easy and cheap solution to housing. Even though this technique fell into disuse in developed countries when concrete appeared in the building sector, some years ago some researchers have started to recover it as a sustainable system. Taylor et al. [8] evaluated a two-storey rammed earth academic office building in Australia since according to users, thermal comfort was not adequate in either summer or winter. Simulations showed that wall conduction rate, infiltration and night ventilation are the weak points of the building, as well as the reason of its bad thermal performance, not the materials of the building.

Another example of current earth construction is the Brighton Earthship, where Ip and Miller [9] evaluated a building located in Brighton (UK) with a rammed earth-sheltered wall that worked as a long term thermal storage unit (Fig. 4). Results showed that the thermal storage contributed to maintain more stable indoor conditions during winter, but a heating system was still needed to reach comfort conditions.

\subsubsection{Concrete}

An insulated concrete wall system T-Mass ${ }^{\mathrm{TM}}$ by the Dow Chemical Company was used on the exterior walls of a zero energy house presented by Zhu et al. [10]. The thermal functions of this concrete wall were investigated using experimental data in comparison to a conventional wood frame system. The authors concluded that the thermal mass wall would have a bigger effect in a desert climate than in more moderate ones.

A similar comparison was undertaken by Dodoo et al. [11], which analysed the effect of thermal mass on space heating energy use and life cycle primary energy balance of a concrete and a woodframe building by dynamic modelling of heat flows in building mass configurations. The results indicated that the energy savings due to thermal mass is small and varies with the climatic location and energy efficiency levels of the buildings. Therefore, the authors concluded that the influence of thermal mass on space heating use for buildings located in Nordic climates is small.

An interesting application of the concrete thermal mass was done by Ünalan and Özrahat [12]. Authors investigated the storage possibility of sensible thermal energy in the concrete columns of multi-storey buildings and the heating performance of the indoor environment with the stored energy in Kayseri city (Turkey). They used simplified transient calculations of a concrete hollow cylindrical column, achieving very attractive results in terms of the building heating systems.

\subsubsection{Alveolar brick}

Brick constructions are also known to have high thermal mass. De Gracia et al. [13] studied the thermal inertia of alveolar brick systems. A typical Mediterranean brick construction system which included insulation was theoretically and experimentally compared 

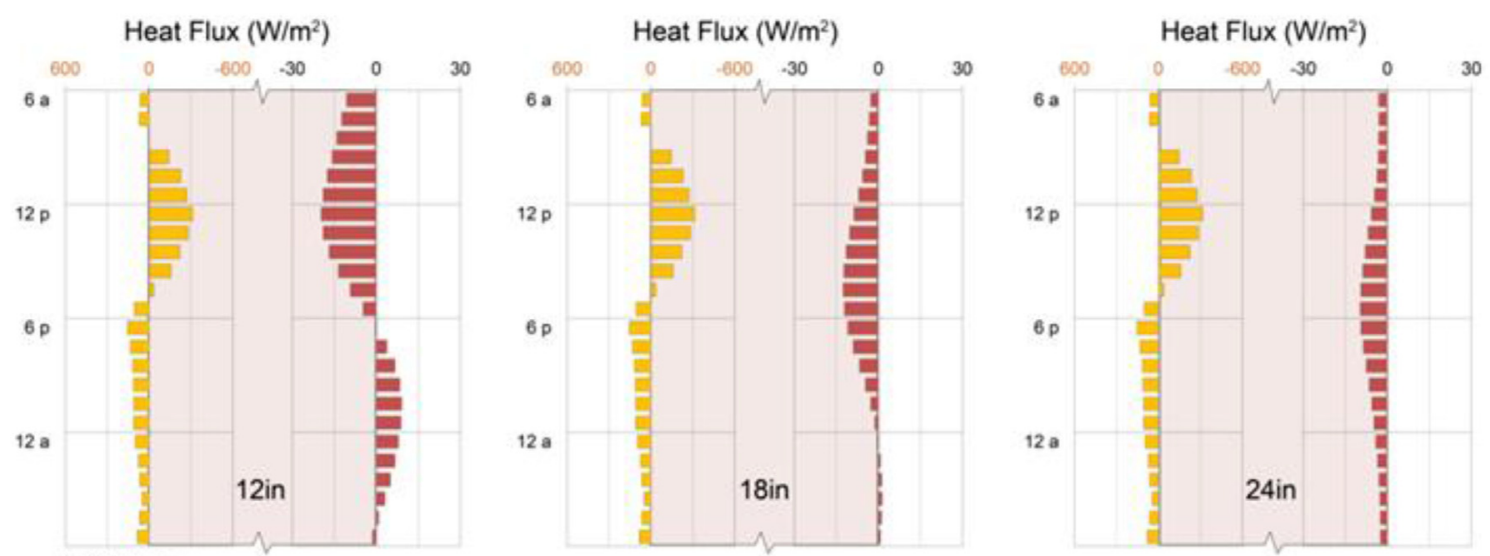

(a) Adobe
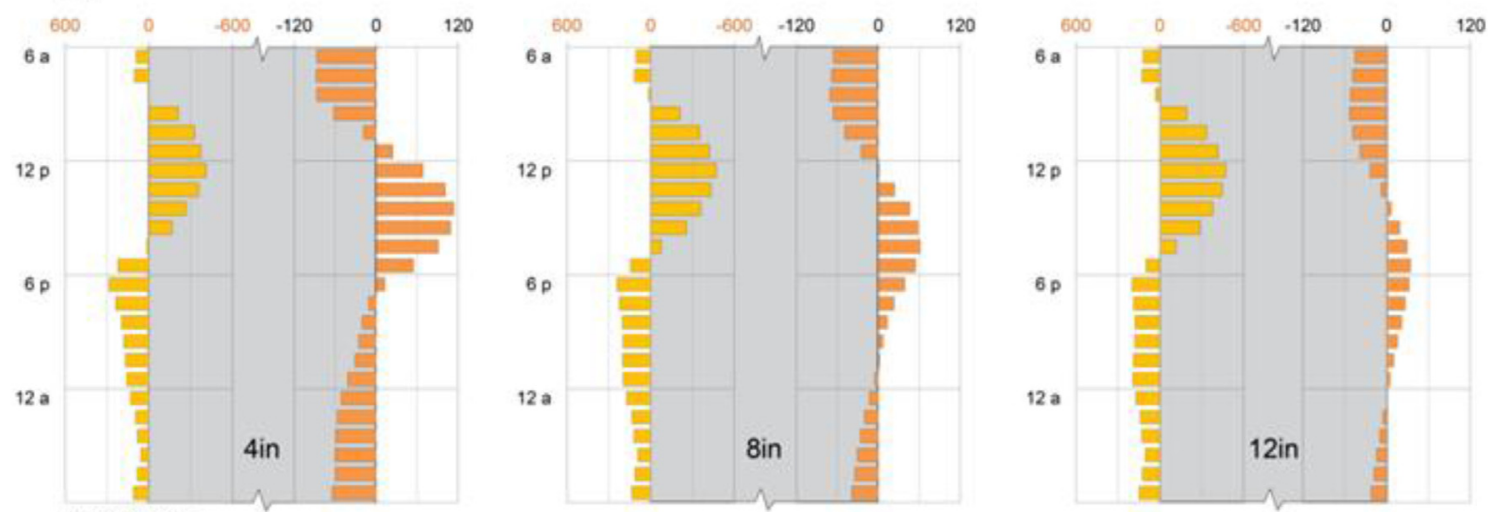

(b) Granite

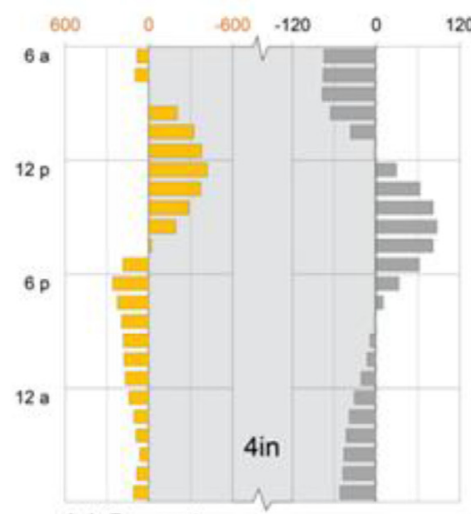

(c) Concrete

Solar heat gain

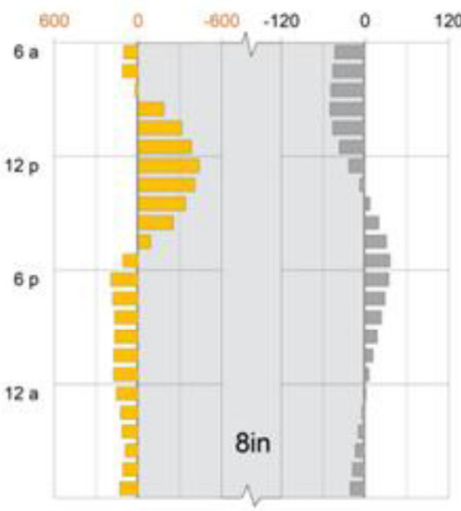

Heat release to indoor space (adobe)

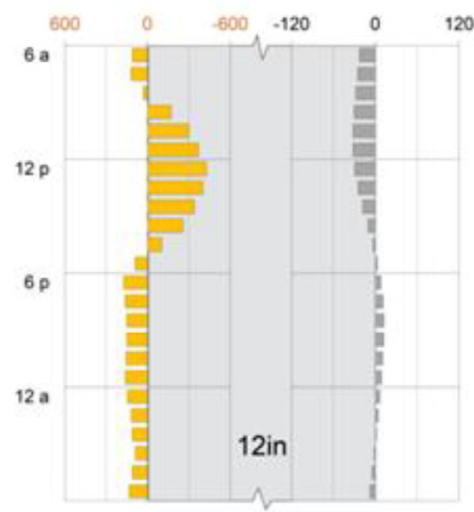

Heat release to indoor space (concrete)

\section{Heat release to indoor space (granite)}

Fig. 2. Exterior mass walls. Heat fluxes across outdoor (left axis) and indoor (right axis) surfaces of exterior walls on a typical sunny January day in Denver, Colorado [5].

to an alveolar brick system without insulation. The U-value study resulted in a reduction of $45 \%$ for the insulated system, while the HVAC system energy consumption was $2 \%$ and $13 \%$ more for the alveolar brick system during winter and summer periods, respectively. The authors concluded that, although the U-value is a design parameter usually required by building regulations, transient parameters should always be taken into account otherwise appropriate construction systems might be discarded in the design process of buildings.

\subsection{Solar walls}

According to Saadatian et al. [14] solar walls offer a feasible technique for the exploitation of directional flow of heat in buildings. These authors reviewed the state-of-the-art concepts, applications and significance of solar walls for energy savings in 


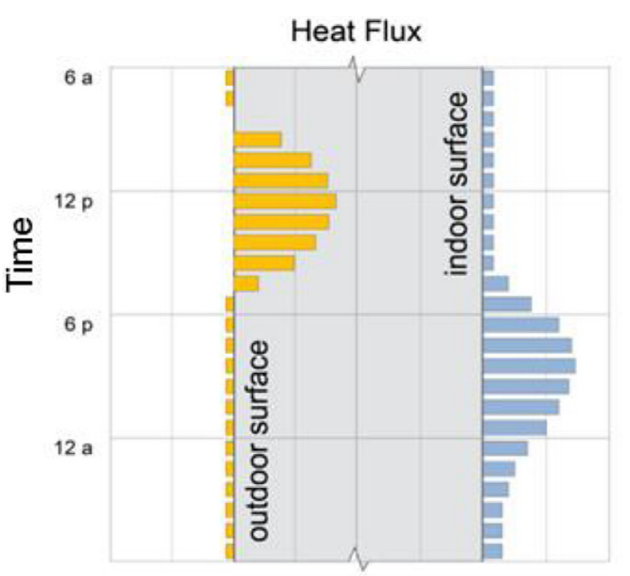

(a) Residential (Evening) Heating

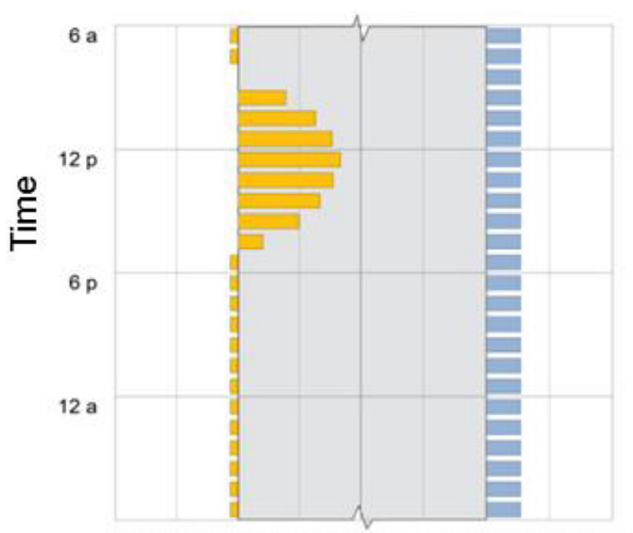

(c) Greenhouse (All-Night) Heating

\section{Heat release to indoor space}

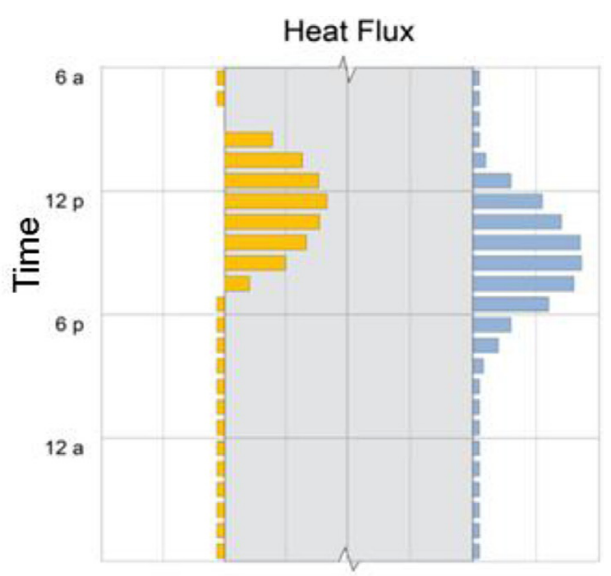

(b) Workplace (Afternoon) Heating

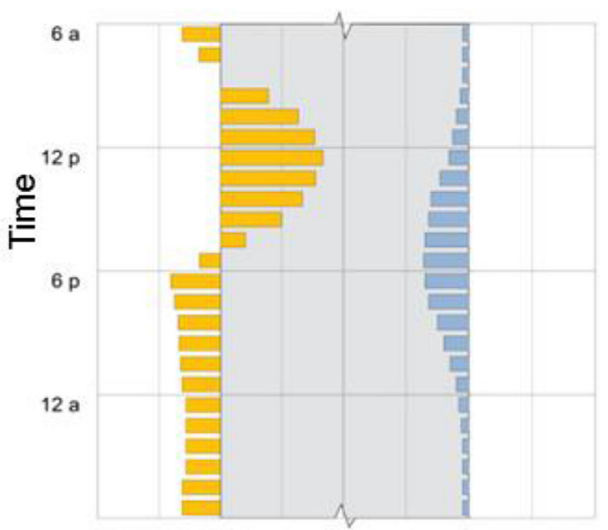

(d) Cooling

\section{Solar heat gain}

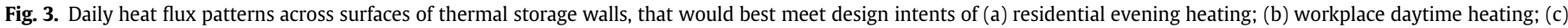
sunspace or greenhouse all-night heating; and (d) cooling [5].

buildings giving a detailed operational framework of various solarwall configurations, technology and efficiency as a building component. Solar walls were classified by these authors dividing them as standard solar wall (Trombe wall), solar water wall, solar transwall, composite solar wall, and fluidised solar wall. Out of these types, only the Trombe wall and the solar water wall include storage in their operation.

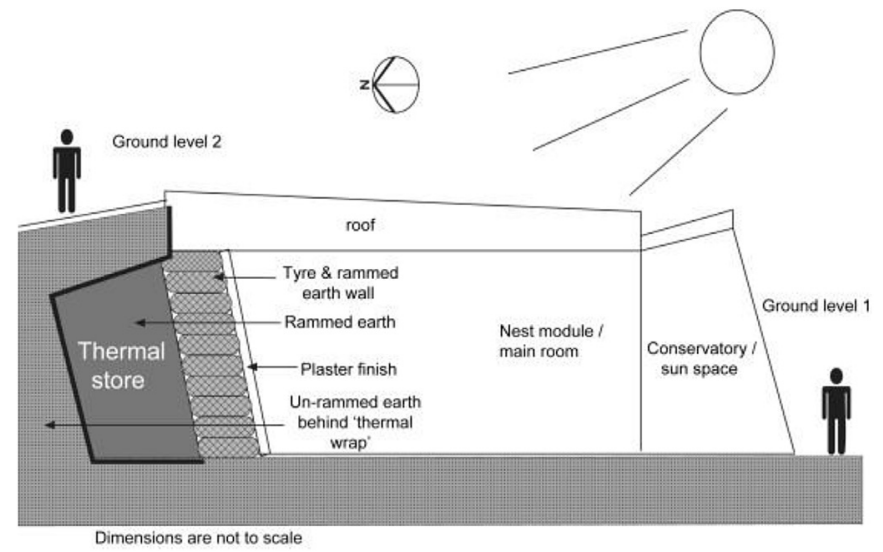

Fig. 4. Section of the Brighton Earthship building [9].

\subsubsection{Standard solar wall or Trombe wall}

The concept of a standard solar wall was developed and patented by Edward Morse in 1881. However, this passive wall system is popularly known as a Trombe wall because Felix Trombe started to apply it in the late 1950s [14]. Typical Trombe walls consist of a high thermal mass wall made by concrete, stone, bricks or earth, covered by glass leaving an air channel between both components. The operating principle of the Trombe wall could have different configurations (Fig. 5) depending on the purpose, the climate, and the season [15].

The thermal performance of Trombe walls has been widely studied and experimental and simulated investigations can be found in the literature about the energetic benefits of this passive system [16,17]. The original principle was also modified by combining natural or mechanical ventilation [18], different air gap thicknesses, or even the importance of having dark paint [19].

\subsubsection{Solar water wall}

Solar water wall follows the same principle as the standard solar wall. However, the concrete, brick or stone is replaced by water containers forming a wall. Many designers have focused their interest in water since its specific heat is higher than typical materials used in Trombe walls. However, heat transfer in this case occurs faster than in standard solar walls, so sometimes an insulated glass layer should be placed in front of the water containers [20]. 
a

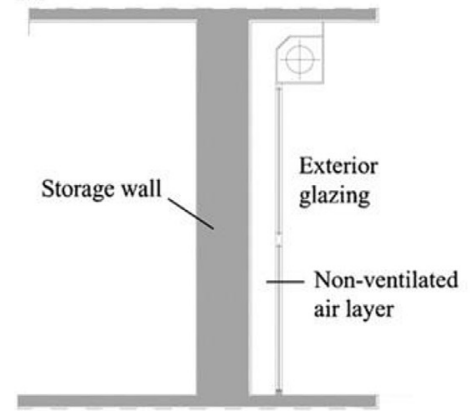

b

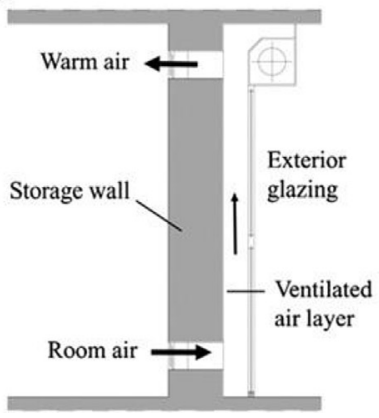

C

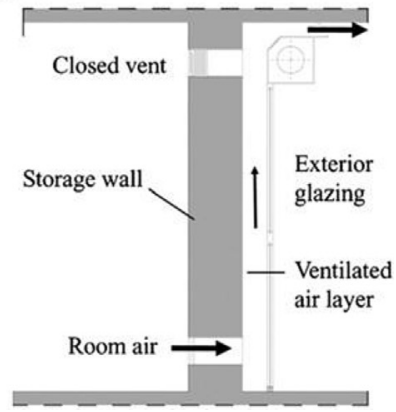

Fig. 5. Trombe wall configurations a) without ventilation, b) winter mode with air circulation, c) summer mode with cross ventilation [15].

The thickness of a solar water wall and its effect on the wall performance was experimentally studied by Adams et al. [21]. Authors concluded that the thicker the wall is the higher energy storage capacity it has. Moreover, this passive system could be used for cooling and heating purposes smoothing the internal ambient temperature of the building. However, the inclusion of water as a material in building components has several difficulties such as the containers distribution or condensation problems, among others [22].

\section{Latent heat storage}

Latent heat is obtained when a change in the phase state of a material occurs. During the solid-liquid phase change, which is the most used process because of its easy controllable conditions, temperature remains constant and the material can store large amounts of heat. In this case, latent heat storage applications used the melting and solidification processes to store and release heat in phase change materials (PCM) [3].

\subsection{Incorporation of PCM in construction materials}

Memon [23] described six methods of incorporating PCMs into construction materials: direct incorporation, immersion, vacuum impregnation, encapsulation, shape-stabilisation, and form stable composites.

\subsubsection{Direct incorporation}

Direct incorporation is a relatively simple method in which the liquid or powder phase change material is added directly to a wet mix of the construction material, e.g. concrete, mortar or gypsum, during production. Feldman et al. [24] carried out a study in which an energy storage gypsum wallboard was produced by the direct incorporation of $22 \%$ commercial grade butyl stearate at the mixing stage of the gypsum board production. Dispersion agents had to be used to ensure an even distribution. The physical and mechanical properties of the PCM gypsum wallboard compared well with the standard board and the energy storage capacity showed a tenfold increase. However, Soares et al. [25] reported that problems of leakage and possible incompatibility with some building materials may occur. To successfully use this method with concrete it is important to ensure that PCM does not interfere with the hydration process, adversely affect the bond between the aggregate and the cement, adversely affect the mechanical properties of the concrete, or adversely affect the durability of the end product.

There appears to be a scarcity of research studies in which a PCM was directly added to concrete without being encapsulated in some form prior to incorporation. When the PCM is directly added to the concrete mix there is no barrier between the two materials and hence there is a higher risk of the PCM having an adverse effect on the concrete properties. In general terms, when using PCM direct incorporation, especially with cement based materials, attention should be paid to not interfere the hydration process [24] as it could affect the bonding between paste and aggregate, the mechanical properties and the durability properties [25].

\subsubsection{Immersion}

In the immersion technique porous construction elements (concrete blocks, gypsum wallboard, porous aggregate, timber, etc.) are immersed in a container that is filled with a liquid PCM. The PCM is absorbed by capillary action. The time required for effective absorption of the liquid PCM depends on three criteria, the absorption capacity of the construction element, the temperature of the PCM, and the viscosity of the PCM. The immersion process normally takes a number of hours [26].

Hawes et al. [27] studied the absorptivity of PCMs into autoclaved concrete blocks and regular concrete blocks at a temperature of $80{ }^{\circ} \mathrm{C}$. The time required to fully soak the autoclaved concrete blocks with butyl stearate and paraffin was between $40 \mathrm{~min}$ and $1 \mathrm{~h}$. The regular concrete blocks required an immersion time of $6 \mathrm{~h}$ to be fully soaked with paraffin. The study concluded that the autoclaved blocks were a better choice for immersion due to their higher porosity and also the higher the temperature of the PCM the higher the rate of absorption.

Lee et al. [28] also incorporated butyl stearate and paraffin into autoclaved and regular concrete blocks. However they observed that some of the paraffin leaked out during the heating cycles resulting in a thin film of paraffin remaining on the surface of the regular concrete blocks.

Bentz and Turpin [29] investigated a number of applications for PCM/concrete applications. One of the methods that they adopted to incorporate PCM into concrete was to immerse a porous aggregate (expanded shale, $3 \mathrm{~mm}$ dia.) in liquid paraffin. The aggregate was first dried at $40{ }^{\circ} \mathrm{C}$ and then soaked in the liquid paraffin for a minimum of $24 \mathrm{~h}$. They obtained absorption of $13.8 \%$ by mass of dry aggregate. This PCM aggregate was then used in a concrete mix for a number of applications. An interesting finding of their study was that the heat transfer between concrete matrix and the PCM was better in the concrete samples that were made with the PCM aggregate compared to the samples made by direct mixing of the PCM into the fresh concrete (as described in 3.1.2). Paraffin has a low conductivity however embedding it in a more thermally conductive material enhanced the heat transfer between the PCM and concrete matrix.

On the other hand, the immersion of PCM into gypsum material was tested by Bajare et al. [30]. A porous gypsum material was 
dipped during $1 \mathrm{~h}$ into liquid paraffins and salt hydrates. The samples immersed in paraffin absorbed higher PCM content that the salt hydrates ones. Moreover, salt hydrates samples presented a decrease on the compressive strength of $50 \%$ being unacceptable properties for construction, while paraffins show low reduction percentages $(3 \%-4 \%)$. Authors concluded that paraffins are more convenient for the immersion method implementation in gypsum material.

As well as the direct incorporation method, immersion method reported some leakage problems may occur especially after subjected to large number of thermal cycles [25], and also incompatibility problems with some construction materials [27].

\subsubsection{Vacuum impregnation}

The vacuum impregnation method involves firstly evacuating the air from porous aggregates using a vacuum pump. The porous aggregates are then soaked in a liquid PCM under vacuum. Zhang et al. [31] studied the vacuum impregnation of PCM into a granular material that can be added to building materials such as concrete. Fig. 6 shows a schematic of the vacuum impregnation set up.

A comparative study was presented by Barreneche et al. [32] several gypsum samples with different PCM incorporation methods (microencapsulation, direct incorporation and impregnation) were studied. Found that the effective thermal conductivity decreased in all samples except in the impregnated one. This fact was due to the substitution of the air by the PCM in liquid state and hence decreasing the porosity of the sample.

The ability of different types of porous aggregate to absorb butyl stearate was studied by Zhang et al. [33]. The three aggregate types investigated were expanded clay (C1), normal clay (C2) and expanded shale (S). Table 1 below shows the PCM absorbing capacity for the porous aggregates.

It can be seen that the porous structure of the aggregate affects the volume of PCM that is absorbed. These aggregates were subsequently used to make concrete samples and it was shown as would be expected, that the enthalpy of the PCM concrete composite sample during phase change increased linearly with the volume fraction of the PCM in concrete.

In a later study, Zhang et al. [34] carried out similar experiments on expanded perlite (PE), two types of expanded clay (SZ \& SL) and expanded fly ash granules (FL) and they used a range of organic PCMs all of which had a viscosity between 2 and $10 \mathrm{mPa}$. They used both the vacuum impregnation method and immersion method to incorporate the PCM into the aggregates. For the vacuum

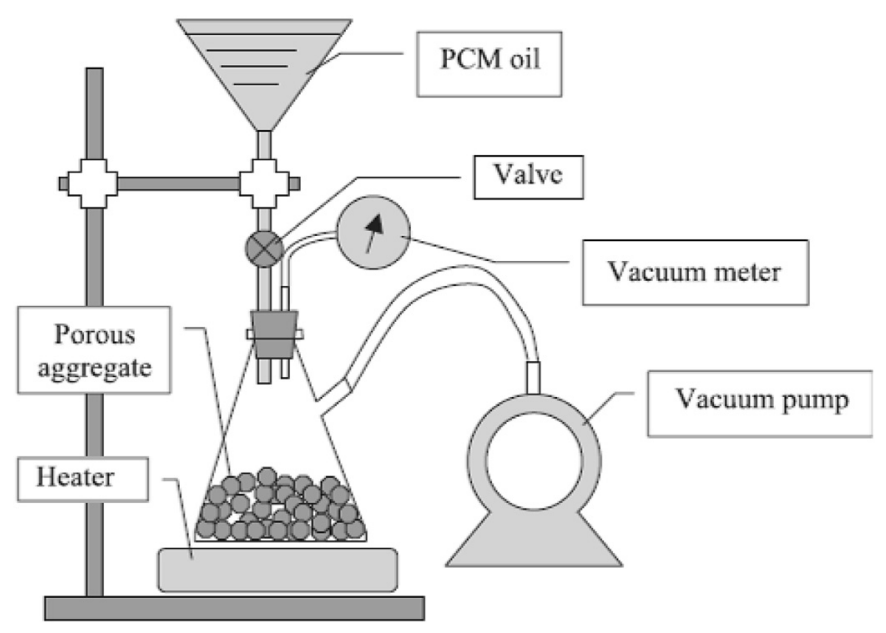

Fig. 6. Schematic of the vacuum impregnation set up [31]. impregnation method it was found that an immersion time of $30 \mathrm{~min}$ at a temperature of $30^{\circ} \mathrm{C}$ above the melting temperature of the PCM optimises the absorption of PCM. In the natural immersion method the aggregates were soaked for $1 \mathrm{~h}$. A comparison of absorption volumes for each method are summarised in Fig. 7. All combinations of the PCM aggregates were found to be chemically compatible, non-toxic and had a large thermal energy storage density.

Vacuum impregnation method is considered to be a more effective method of incorporation. No other advantage is demonstrated in the literature.

\subsection{Encapsulation of phase change materials}

Phase change materials can be encapsulated prior to incorporating them into building elements. Regin et al. [35] stated four primary functions of the containment capsule: (i) meet the requirements of strength, flexibility, corrosion resistance and thermal stability, (ii) act as a barrier to protect the phase change material from harmful interaction with the environment, (iii) provide sufficient surface for heat transfer, and (iv) provide structural stability and easy handling.

There are two forms of encapsulation, macro-encapsulation and micro-encapsulation, but, form stabilized PCM is also being developed to be used in building walls.

\subsubsection{Macro-encapsulation}

In macro-encapsulation the phase change materials are packaged into containers such as tubes, spheres or panels $(>10 \mathrm{~mm}$ in diameter/thickness, Cabeza et al. [36]), which are then incorporated into building components. The macrocapsules must be designed to suit the particular application. The thermal and geometrical parameters of the container have a direct influence on the heat transfer characteristics of the PCM and they affect the melting time and performance of the PCM element. Hence the capsule should be designed to optimize the heat transfer rate and also to eliminate leakage, corrosion and problems related to the change in volume of the PCM [24].

Previous research with macro-encapsulation failed due to poor conductivity of the phase change material. When the heat energy is being released from the PCM capsule the PCM solidifies around the edges of the capsule and prevents effective heat transfer [37]. Also the heat transfer from the PCM is limited by the surface area of the capsules and hence it can be difficult to achieve sufficient area for the required heat transfer. Other practical disadvantages of using macro-encapsulated PCMs in buildings is that there is a risk that they could get damaged during the use of the building, e.g. drilling nails into walls, and also there is extra work required on site to integrate the capsules into the structure.

\subsubsection{Micro-encapsulation}

Walls and floors of buildings provide large surface area to facilitate heat transfer. The most commonly used method for incorporating PCMs into construction materials is microencapsulation, where small PCM particles $(1 \mu \mathrm{m}-1000 \mu \mathrm{m})$ are encapsulated in a thin solid shell which is made from natural and synthetic polymers. These microcapsules can then be directly added to the construction material e.g. concrete or plaster, during their mixing process. This method allows the possibility of providing a PCM composite over a large area and hence it has the advantage of a high heat transfer rate per unit volume. Other advantages are that the capsules prevent leakage and resist volume change during phase change. They also have improved chemical stability and thermal reliability as phase separation during transition is limited to microscopic distances. However, the 
Table 1

PCM absorbing capacity for the porous aggregates [33].

\begin{tabular}{|c|c|c|c|c|c|}
\hline Notation & $\begin{array}{l}\text { Density } \\
\left(\mathrm{g} / \mathrm{cm}^{3}\right)\end{array}$ & Porosity (\%) (MIP) & $\begin{array}{l}\text { Water-absorbing capacity } \\
\text { by simple immersion (\%) }\end{array}$ & $\begin{array}{l}\text { Water-absorbing capacity by } \\
\text { vacuum impregnation (\%) }\end{array}$ & $\begin{array}{l}\text { PCM-absorbing capacity }(\mathrm{ml}) \\
\text { per } 1 \mathrm{~g} \text { of porous aggregate }\end{array}$ \\
\hline $\mathrm{C} 1$ & 0.76 & 75.6 & 11.0 & 72.5 & 0.876 \\
\hline $\mathrm{C} 2$ & 1.25 & 41.9 & 5.9 & 42.5 & 0.176 \\
\hline S & 1.39 & 33.8 & 4.1 & 15.0 & 0.081 \\
\hline
\end{tabular}

microcapsules can affect the mechanical properties of concrete and they are also relatively expensive [23].

It is important that the capsule itself is physically and chemically stable within the concrete matrix. The capsule needs to be hard and sustainable to avoid being damaged during the concrete mixing and casting process. Park et al. [38] discussed the use of zeolite and zeocarbon that some researchers have used for reinforcing microcapsules to enable them to withstand high friction and impact during the concrete mixing process.

A number of researchers have carried out studies using microencapsulated PCMs in concrete. Hunger et al. [39] investigated the behaviour and properties of self-compacting concrete mixes that contained $1 \%, 3 \%$ and $5 \%$ of microencapsulated PCM by mass of concrete. A self-compacting concrete mix was used to mitigate damage to the microcapsules during compaction. Also the PCM was added to the mix at the latest possible moment to reduce its exposure to the mixing process. The primary aim of their research was to reduce the peak temperature of hydration so a high dosage of cement was used $\left(450 \mathrm{~kg} / \mathrm{m}^{3}\right)$. The authors also recommended that stronger shells for the micro-encapsulated PCM to be used in future applications to ensure that the capsules can withstand the high alkaline environment and mechanical impact during mixing.

Another study in which micro-encapsulated high purity paraffin PCM in an aqueous dispersion was added to self-compacting concrete was carried out by Fenollera et al. [40]. PCM dosages of 5\%, $10 \%, 15 \%, 20 \%$ and $25 \%$ of mass of cement were added to a selfcompacting concrete mix and the slump, compressive strength and density were compared in order to find an optimum combination. In this study authors stated the following:

- As the percentage of PCM increases the deformation capacity of the fresh self-compacting concrete decreases as well as the concrete viscosity and cohesion.

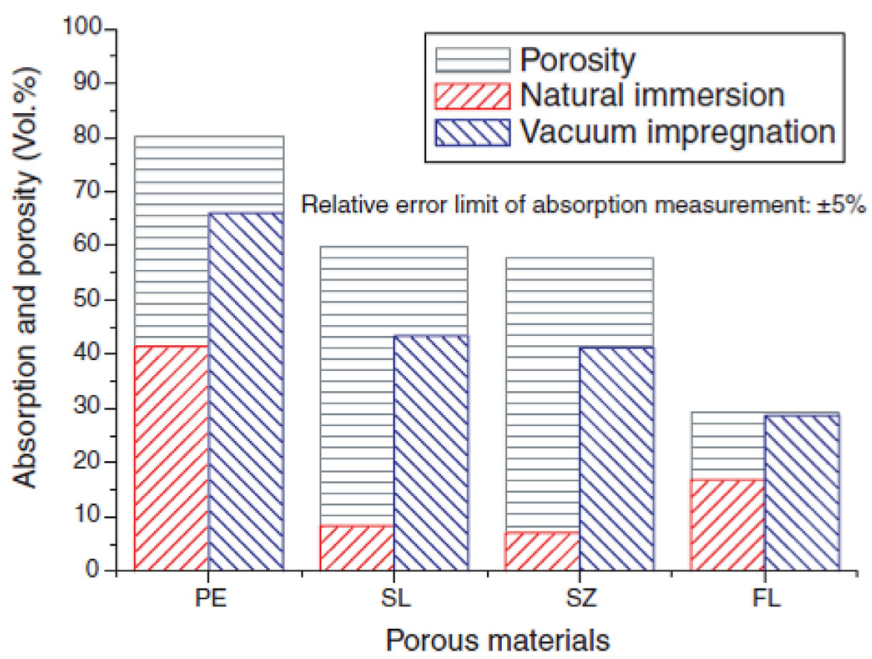

Fig. 7. Comparison between vacuum impregnation and natural immersion [34].
- As the percentage of PCM increases the density of both the fresh and hardened concrete decreases. There was a large decrease in the sample with $25 \%$ PCM $\left(2372 \mathrm{~kg} / \mathrm{m}^{3}\right.$ to $\left.1967 \mathrm{~kg} / \mathrm{m}^{3}\right)$

- The compressive test results are shown in Table 2 . The strength decreases by $7 \%$ for each $5 \%$ of PCM added with a further decrease for the sample with $25 \%$ PCM. The viability of the samples with $20 \%$ and $25 \%$ was discarded due to their low compressive strengths and also poor homogenization of the mixtures.

- Thermal conductivity decreased by $25 \%$ in the sample with $10 \%$ PCM. The decrease in thermal conductivity was expected due to the decrease in density and also the low conductivity of paraffin.

From the above two studies it can be concluded that 10\% (by weight of cement) or $5 \%$ by weight of concrete, is the maximum practical content of micro-encapsulated PCM to be used in a concrete mix application.

A large proportion of the research that has been carried out on phase change materials incorporated into concrete or plaster has used micro-encapsulated organic phase change materials. The distribution of the small PCM containing capsules provides a large heat exchange surface. The microcapsules are relatively easy to incorporate into the construction material during the mixing process and there is no additional site work required. There is also no need to protect the PCM capsules from destruction such as post fixed nails etc. However it is clear that there is a limit to the quantity of PCM that can be incorporated into the construction materials and also the microcapsules have a significant negative effect on the mechanical strength of the matrix material. A number of researchers have shown that it is feasible to create a microencapsulated PCM/concrete composite that can achieve compressive strengths within the range suitable for use in building structures, $\left(25 \mathrm{~N} / \mathrm{mm}^{2}-35 \mathrm{~N} / \mathrm{mm}^{2}\right.$ characteristic).

\subsubsection{Shape stabilisation and form-stable PCM}

In the shape stabilising technique a supporting material such as high density polyethylene (HDPE) is melted with a PCM and they are mixed at high temperature. The mixture is then cooled below the glass transition temperature of the supporting material until it becomes solid. This method allows a PCM content of up to $80 \%$ by mass. Some studies [41,42] noted that this method produces a composite material with a high specific heat and an appropriate thermal conductivity that is thermally reliable over a long time period.

Table 2

Compressive strength test results, Fenollera et al. [40].

\begin{tabular}{lllllll}
\hline Specimen breakage & \multicolumn{6}{l}{ Percentage of PCM } \\
\cline { 2 - 7 } & \multicolumn{7}{l}{$0 \%$} & $5 \%$ & $10 \%$ & $15 \%$ & $20 \%$ & $25 \%$ \\
\cline { 2 - 7 } & 50.02 & 47.70 & 43.65 & 36.40 & 32.20 & 12.10 \\
\hline Compressive strength $\left(\mathrm{N} / \mathrm{mm}^{2}\right)$ & & & \\
\hline 2 days & 54.70 & 51.00 & 48.65 & 43.25 & 38.85 & 20.10 \\
60 days & 60.10 & 55.00 & 51.20 & 48.60 & 42.05 & 20.20 \\
\hline
\end{tabular}


Another type of composite PCM is known as form-stable composite PCM. A form-stable composite PCM retains an optimum percentage of phase change material with no leakage above the melting temperature of the PCM. The terms 'form-stable' and 'shape stabilized' appear to be used interchangeably in some research [42], however with form-stable composites it is not necessary for the supporting material to be melted. Form-stable composites use immersion and vacuum impregnation methods to incorporate the PCM into the supporting materials $[43,44]$.

Memon [23] presented a detailed summary of research carried out using form-stable PCMs. Most of the research studied the formation of form-stable PCMs; however, there appears to be a lack of research on the application of these composite materials. The type of supporting materials used included, diatomite, expanded perlite, expanded graphite, silica fume and ground granular blast furnace slag (GGBS). GGBS is commonly used as a partial cement replacement in concrete so its use as a supporting material for a form-stable PCM composite is of interest. A phase change material, dodecyl alcohol (DA) was incorporated into the GGBS using vacuum impregnation in a study of Memon et al. [45]. The maximum percentage of PCM retained without leakage was $11 \%$ by weight. The composite had a melting temperature of $21.16{ }^{\circ} \mathrm{C}$ and a latent heat of $22 \mathrm{~J} / \mathrm{g}$. Further research is required to establish if this composite can be successfully used to effectively increase the thermal energy storage of a building. As the amount of GGBS that can be used as cement replacement in concrete is usually limited to $30 \%$ of total cement content it may not be feasible to incorporate a sufficient amount of PCM into the structure to make an effective difference to the thermal storage capacity of the building.

\subsection{Effect of the PCM incorporation method on the properties of concrete}

\subsubsection{Workability}

Hunger et al. [39] investigated the effect of micro-encapsulated phase change material on the slump of a self-compacting concrete and found that all three PCM composites, $1 \%, 3 \%$ and $5 \%$ by mass had similar flow diameters. The $3 \%$ and $5 \%$ mixes exhibited a slightly higher viscosity however the self-compacting properties were not compromised.

Pomianowski et al. [46] although not investigating workability, indicated that one of the mixes used in their study that contained 6\% micro-encapsulated PCM showed poor workability despite the use of a plasticiser and the mix was excluded from further investigation. Moreover, Fenollera et al. [40] also studied the effect of micro-encapsulated PCMs on the slump of a self-compacting concrete. The dosages of micro-encapsulated PCM were 5\%, 10\%, 15\%, $20 \%$ and $25 \%$ by weight of cement. The slump flow test results are shown in Table 3.

For a self-compacting concrete the allowable flow diameter, $\mathrm{d}_{\mathrm{f}}$ range is $550 \mathrm{~mm}-850 \mathrm{~mm}$ hence it can be noted that the $20 \%$ and 25\% PCM mixes do not comply the requirements.

\subsubsection{Heat of hydration}

Bentz and Turpin [29] incorporated both paraffin (PAR) and polyethylene glycol (PEG) by immersion into a lightweight aggregate (expanded shale) that were used to make mortar samples. Another PCM/mortar composite sample was made by direct mixing paraffin wax particles $(1 \mathrm{~mm})$ into the cement paste, replacing a portion of the sand. Thermocouples were placed in the centre of the samples and the temperature of hydration was monitored over a couple of days. It was found that the PEG sample substantially retarded cement hydration thus it was concluded that to use a PEG in a concrete application the PEG would require encapsulation. For the remaining two samples a reduction in peak temperature of $8{ }^{\circ} \mathrm{C}$ and a delay in reaching peak temperature of $1 \mathrm{~h}$ were observed. It was proposed that if $20 \%$ of the aggregate mass of a typical concrete mix could be replaced with lightweight aggregate impregnated with paraffin wax there could potentially be $350 \mathrm{~kg} / \mathrm{m}^{3}$ of PCM in the concrete. This amount of PCM could potentially reduce the peak temperature of hydration by $25 \%$.

Hunger et al. [39] also concluded that an increasing amount of PCM results in a lower peak temperature of hydration. The research found that the peak hydration temperature could be reduced up to $28 \%$ by increasing PCM content to $5 \%$ by weight of concrete. However the heating rate did not change hence the emission of heat from the sample will therefore continue for a longer time when the PCM content is higher.

\subsubsection{Compressive strength}

All the literature reviewed that considered micro-encapsulated phase change materials in concrete, recorded a linear reduction in compressive strength of the PCM/concrete composite. Fig. 8 shows a reduction in compressive strength of $7 \%$ for each $5 \%$ increase in micro-encapsulated PCM (by weight of cement) in a selfcompacting concrete mix observed by Fenollera et al. [40].

Hunger et al. [39] also reported a $13 \%$ decrease in compressive strength for every $1 \%$ (by weight of concrete) increase in the microencapsulated PCM content. These findings are to be expected as there is a significant difference between the intrinsic strength of the microcapsules and the other constituents of the concrete such as aggregates and cement.

In Eddhahak-Ouni et al. [47] tested the incorporation of microencapsulated paraffin PCM in Portland cement concrete samples in $1 \%, 3 \%$ and $5 \%$ by volume. The compressive strength of the samples decreased as the percentage of PCM increased. There was a $32 \%$ decrease in compressive strength between the reference sample and the sample with 5\% PCM.

On a research study, Hawes et al. [27] used the immersion method to incorporate the phase change material into concrete. It was found that there was no significant difference in the compressive strength when the paraffin was in a liquid state and that there was a 50\% increase in strength when paraffin was in a solid state.

Notice that studies presented show high results disparity. Authors assume that with the data presented in the publications it is

Table 3

Results of slump flow tests [40].

\begin{tabular}{|c|c|c|c|c|c|c|c|}
\hline \multirow[t]{2}{*}{ Test } & \multirow[t]{2}{*}{ Parameter } & \multicolumn{6}{|c|}{ Percentage of PCM in the mix } \\
\hline & & $0 \%$ & $5 \%$ & $10 \%$ & $15 \%$ & $20 \%$ & $25 \%$ \\
\hline \multirow[t]{2}{*}{ Slump flow test } & $\mathrm{T}_{50}(\mathrm{~s})$ & 8 & 7 & 8 & 6 & 8 & - \\
\hline & $\mathrm{d}_{\mathrm{f}}(\mathrm{mm})$ & 690 & 650 & 640 & 640 & $530-520$ & Cone $22 \mathrm{~cm}$ \\
\hline \multirow[t]{2}{*}{ Classification according to EFNARC ${ }^{a}$} & Viscosity & vS2 & VS2 & VS2 & VS2 & VS2 & - \\
\hline & Slump flow & SF2 & SF1 & SF1 & SF1 & - & - \\
\hline
\end{tabular}

a EFNARC (European Federation of National Associations Representing for Concrete). 


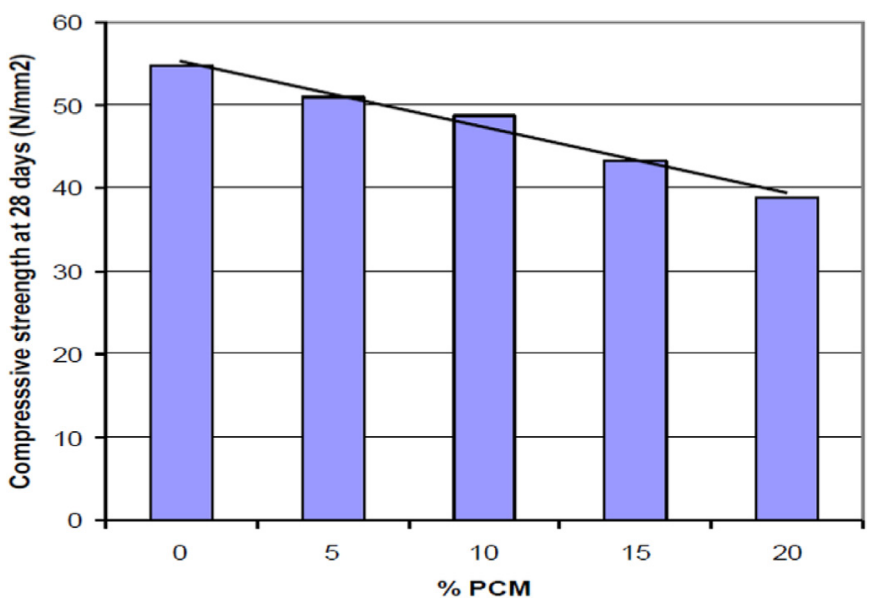

Fig. 8. 28 day strengths for micro-encapsulated PCM/concrete composite [40].

not possible to assess what is the reason for the difference in mechanical strength performance change when PCM is added.

There was no report found on the compressive strength of concrete made with PCM impregnated lightweight aggregate. However, it is expected that the compressive strength would be similar to a non-PCM concrete made with the same type of lightweight aggregate as the PCM only replaces air in the aggregates and does not replace any of the cement content. Nevertheless there could be a risk that leakage of the liquid PCM could adversely affect the cement aggregate bond which could lead to a reduced strength of concrete.

\subsubsection{Density}

A reduction in density is expected when a quantity of microencapsulated PCM is added to concrete as a proportion of the cement and aggregate is being replaced by lower density materials (typical density of PCM $=0.915 \mathrm{~g} / \mathrm{cm}^{3}$ ). Hunger et al. [39] observed a decrease in the density of a self-compacting concrete with microencapsulated PCM (Fig. 9).

The decrease in density is accompanied by an increase in porosity which indicates that the microcapsules are altering the concrete packing density. Fenollera et al. [40] also observed a reduction of $1.1 \%$ in density for every additional $5 \%$ (by weight of cement) of microencapsulated PCM. There were no observations made on the density of concrete made with PCM impregnated lightweight aggregate however given that the PCM is replacing air in the aggregates it is expected that the density would be greater

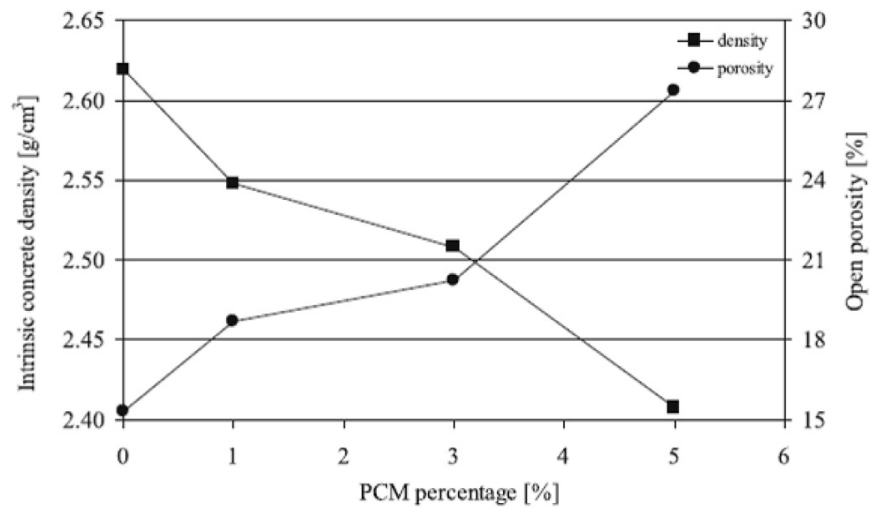

Fig. 9. Density and porosity versus \% of PCM content [39]. than a non-PCM concrete made with the same type of lightweight aggregate. A reduction in density would lead to a reduction in thermal mass of a non-PCM material as:

\section{Thermal mass $=$ mass $\times$ specific heat capacity}

However for a $\mathrm{PCM} /$ concrete composite material the loss in thermal mass due to reduced density is counteracted by the additional thermal storage provided by the latent heat capacity of the phase change material. All the literature reviewed found that there is a significant net benefit in thermal storage achieved by incorporating PCM into concrete. However, it must be noted that a phase change must occur for this benefit to be gained otherwise there will be an overall loss in thermal mass.

\subsubsection{Thermal conductivity}

Organic phase change materials are the PCM typology most used in construction materials. However one of the disadvantages of organic PCMs is that they have low thermal conductivity which can hinder their activation and hence reduce the efficiency of their application. The thermal conductivity of some PCMs can be improved by mixing the PCM with a highly conductive material so that the heat transfer rate between the PCM and the concrete matrix is increased. Li et al. [48] made a form stable PCM by using expanded graphite as a supporting material for paraffin. They found that the latent heat of the form stable PCM was less than that of pure paraffin due to the fact that the mass fraction of paraffin in the composite was $85 \%$ and the latent heat of the form stable PCM is provided by the paraffin. However the heating and cooling rate of the form stable PCM was greater than that of paraffin showing an increased conductivity.

The increased porosity associated with an increase in microencapsulated PCM content, would lead to a decrease in thermal conductivity of a concrete/PCM composite. The relative low conductivity of the PCM also contributes to a decrease in the thermal conductivity of the composite. Both Fenollera et al. [40] and Hunger et al. [39] observed a linear decrease in conductivity with an increase in content of microencapsulated PCM (Fig. 10).

Portland cement concrete samples incorporated with $1 \%, 3 \%$ and $5 \%$ by volume of concrete micro-encapsulated paraffin PCM was investigated by Eddhahak-Ouni et al. [47]. The specific heat capacity and thermal conductivity of the samples were compared. In addition the samples were subjected to artificial ageing in a climate test chamber for 50 days and then their thermal conductivity was retested. Authors found that the heat storage capacity of the PCM concrete was significantly improved. The thermal conductivity did not appear to be affected by the PCM. The aged samples displayed the same thermal behaviour as the non-aged samples which

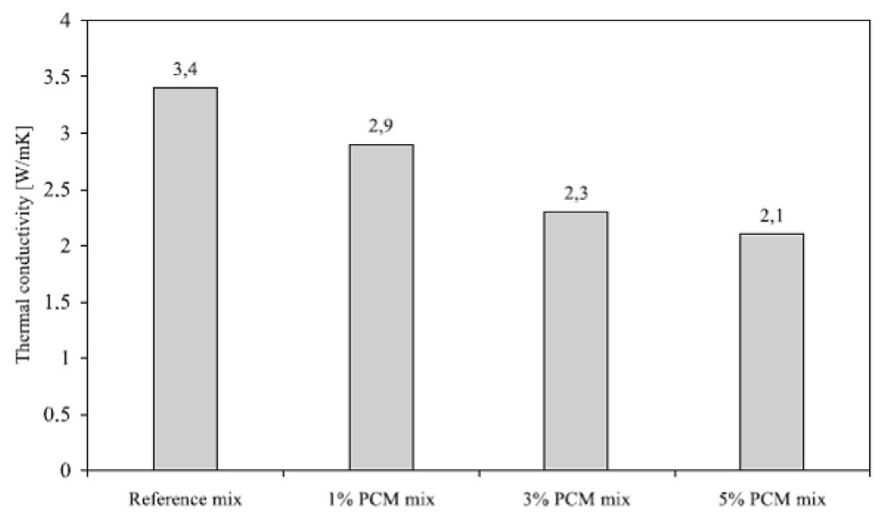

Fig. 10. Thermal conductivity of PCM/concrete composite [39]. 
indicated a stabilised thermal behaviour in the long term.

A reduced thermal conductivity is not necessarily a problem as the desired conductivity of the PCM composite depends on the application. In a thermal storage system for a space heating application it is required that the heat is absorbed and released gradually over a $24 \mathrm{~h}$ period. Hence it is important that the heat flux characteristics of the composite are appropriate to achieve the desired thermal storage behaviour and thermal inertia. It has been shown by a number of researchers that the range of thermal conductivities of PCM/concrete composites is suitable for a diurnal thermal storage period.

\subsubsection{Fire safety}

All materials used in the structure of a building must be able to maintain its mechanical properties for a minimum time period that matches the fire rating of the particular building. The fire rating depends on the use and layout of a building and typically ranges between $1 \mathrm{~h}$ and $4 \mathrm{~h}$. It is critical that any PCM/concrete composite material can provide the required fire resistance if it is to be successfully used in a building application. There appears to be a scarcity of research on this issue. Hawes et al. [27] reported the fire resistance of concrete blocks that had been incorporated with PCM using the immersion technique. The samples were $200 \mathrm{~mm} \times 200 \mathrm{~mm} \times 30 \mathrm{~mm}$ and they were subjected to a $700{ }^{\circ} \mathrm{C}$ flame for $10 \mathrm{~min}$. A reduction in the mass of PCM was observed. Also, in Kolaitis et al. [49] study a PCM evaporation phenomenon was registered in gypsum plasterboards and then implemented and validated in a numerical model. Authors conclude that there exist potential adverse impacts on combusting PCM vapours from gypsum plasterboards, which can be addressed by the addition of flame retardant or application of non-flammable surface coatings.

\section{Latent heat storage. Passive applications in buildings}

Passive systems applied in buildings are designed to reduce the energy demand loads by means of reducing the U-value of the walls or roofs, increasing the thermal inertia of the constructive systems or reducing the incidence of solar radiation. The building envelope is the main location where the studies focus its implementation. Latent heat storage is used to increase the thermal inertia of the construction systems by the addition of phase change materials. Literature reviewed shows different ways to install the PCM based system. A classification was done depending on the method used to incorporate the PCM, distinguishing the inclusion inside the material and the use as a new layer in a construction system, and where the material is embedded.

\subsection{PCM inside the material}

In section 3 different methods of PCM incorporation inside construction materials were presented, as well as the properties of these materials when latent heat storage materials are added. Moreover, in this section studies where the thermal response of building components with PCM incorporated are presented.

\subsubsection{Concrete}

The inclusion of micro-encapsulated PCM in concrete such as Cabeza et al. [50] where two precast concrete house-like cubicles were built in an experimental set-up. One cubicle was made of conventional concrete and the other one of concrete with $5 \%$ of microencapsulated PCM. Results presented a 2 h delay of the maximum peak temperature in summer because of the PCM effect and also an internal temperature profile with lower fluctuations.

\subsubsection{Plaster/gypsum mortar}

Schossig et al. [51] simulated the incorporation of PCM microcapsules into the interior of plaster in a lightweight office with no active cooling system; the melting range of the PCM was $24{ }^{\circ} \mathrm{C}$ to $26{ }^{\circ} \mathrm{C}$. The results showed that the latent heat stored in the PCM during the day reduced the temperature of the wall surface improving the thermal comfort and resulting in a reduction of the cooling load. The simulation was validated on a wall sample $50 \times 50 \mathrm{~cm}$ area. It was found the comfort temperature was maintained for $6 \mathrm{~h}$ longer than with the reference material.

Sá et al. [52] also proposed to add micro-encapsulated PCMs to a wet plaster mix that can then be surface applied to some of the concrete test panels and also to timber and steel test panels. Therefore, the effect of thermal conductivity of the base material on the behaviour of the PCM composites can be assessed. Authors tested a plaster mortar combined with $25 \%$ by mass microencapsulated PCM. The results showed that the addition of the PCM did not compromise the properties of the mortar and that the composite was suitable for a plastering application.

\subsubsection{Others}

Evers et al. [53] mixed into cellulose insulation two types of PCM (paraffin and hydrated-salts) at concentrations of $10 \%$ and $20 \%$ wt. A dynamic wall simulator was used to investigate experimentally the performance of this innovative passive system. It was demonstrated that the paraffin PCM-enhanced insulation reduced the average peak heat flux by up to $9.2 \%$ while the hydrated salt-based PCM did not provide any thermal storage benefit.

Finally, Kosny et al. [54] used a microencapsulated PCM blended with cellulose and fibreglass insulation. The performance of this material as a layer in the core of a building envelope was tested experimentally and theoretically. A dynamic testing procedure demonstrated that the appropriate use of this system can provide a time shift in the heat flow rate oscillation of $3 \mathrm{~h}$. The numerical results highlighted the potential of the material to reduce about 20-35\% peak-hour load during summer period.

In the research studies that carried out full scale tests in rooms constructed with PCM composites, (both gypsum and concrete) it was found in all cases that the peak and minimum daily temperatures were reduced and increased respectively and also the time taken to reach the peak and minimum temperatures was increased. Hence the incorporation of phase change materials into the construction elements of a building improves the stabilising effect of the thermal mass on internal temperatures.

\subsection{PCM as a new layer}

In this concept, the PCM is incorporated inside a construction element or macro-encapsulated and included as another layer, giving thermal inertia to the construction system. The efficiency of these elements depends on several factors such as how the PCM is incorporated in the material; the orientation of the wall with PCM; climatic conditions; direct solar gains; internal gains; ventilation rate; the PCM chosen and its phase-change temperature; the temperature range over which phase-change occurs; and the latent heat capacity per unit area of the wall.

\subsubsection{Gypsum plasterboard}

Gypsum plasterboard is a very commonly used component in new buildings, but it is also an interesting system for refurbishment of old buildings and therefore a good option to improve their energetic performance by the addition of thermal inertia.

Scalat et al. [55] experimentally investigated the effect of the thermal inertia in a test facility when impregnating PCM in plasterboard. Two rooms with dimensions of $2.29 \mathrm{~m} \times 2.27 \mathrm{~m} \times 2.45 \mathrm{~m}$ 
were built for testing. One room contained PCM impregnated gypsum wallboard on the interior walls and ceiling, and the other room had ordinary gypsum walls. An insulated wall separated the two rooms and each of them had an air conditioning unit. The wallboard was immersed in PCM 50\% butyl stearate and $48 \%$ butyl palmitate for 1.5-4 min depending on the dimensions of the wallboard. During winter tests, the air temperature of the room with conventional gypsum wallboard was found to fall from $24^{\circ} \mathrm{C}$ to $16{ }^{\circ} \mathrm{C}$ in $15.1 \mathrm{~h}$; however, the PCM wallboard took $35.5 \mathrm{~h}$ to decrease the same thermal gradient due to the thermally charged PCM. Under cooling mode it was found the ordinary wallboard increased from $16{ }^{\circ} \mathrm{C}$ to $22{ }^{\circ} \mathrm{C}$ in $27.2 \mathrm{~h}$ compared to the PCM wallboard which maintained the temperature below $22^{\circ} \mathrm{C}$ for $50 \mathrm{~h}$. Under real conditions, the effect of room occupancy, lights and other sources of heat from electrical devices may affect the room temperature further than was reflected in these results.

Athientis et al. [56] conducted an experimental and numerical investigation into the impregnation of gypsum wallboards with PCM. A finite difference model was developed which analysed the transient heat process in the walls as seen in Fig. 11.

The model was in agreement with the full-scale experiment. It was found the maximum front surface temperature of the PCM board was $6{ }^{\circ} \mathrm{C}$ lower than the gypsum wallboard. The room air temperature was reduced by $4{ }^{\circ} \mathrm{C}$ using PCM wallboard under summer conditions. Authors concluded that the integration of PCM in wallboard can reduce overheating in buildings.

Experimental investigation into gypsum wallboards integrated with PCM was carried under winter climatic conditions in southeast China by Shilei et al. [57]. PCM wallboard alleviated indoor temperature fluctuations by approximately by $1.15^{\circ} \mathrm{C}$ compared to ordinary wallboards, as seen in Fig. 12.

Moreover, Shilei et al. [58] in a subsequent study tested the transition temperature and latent heat of PCM wallboards by differential scanning calorimetry (DSC). A mixture of capric and lauric acid $(82: 12 \%)$ was incorporated into gypsum wallboard which was $26 \%$ of PCM of total weight of wallboard. The PCM wallboard was tested experimentally by heating an experimental room temperature from $11{ }^{\circ} \mathrm{C}$ to $24{ }^{\circ} \mathrm{C}$. A conventional gypsum wallboard was previously tested to compare the results with the PCM incorporation wallboard. The difference in thermal energy to maintain the two rooms at the same temperature was assumed to be stored as latent heat in the PCM. In summer, the PCM wallboards were found to absorb $39.1 \mathrm{~kJ} / \mathrm{kg}$ beyond a temperature of $18.5^{\circ} \mathrm{C}$ before melting fully at $24{ }^{\circ} \mathrm{C}$. The results show the balance of temperature fluctuation, regulation of room temperature for a more prolonged period and decrease the cold load of air conditioning systems. The

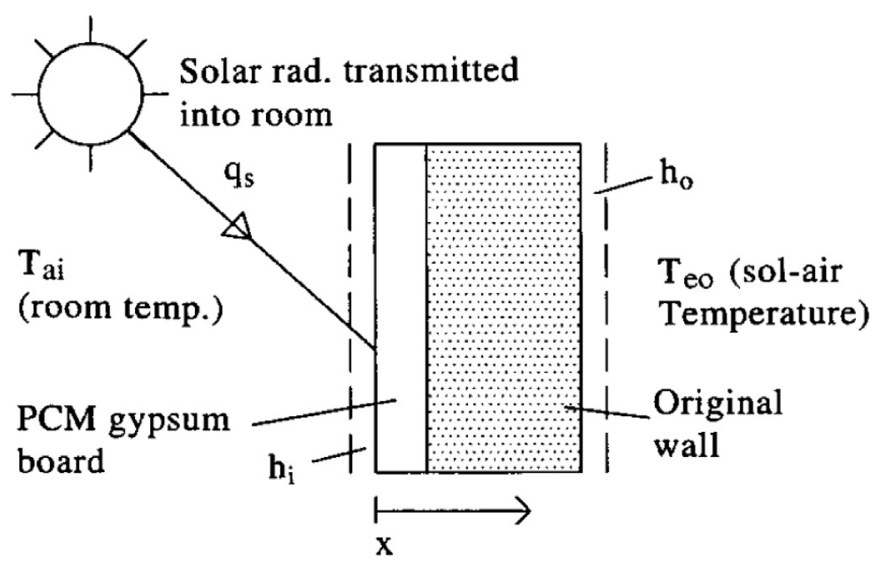

Fig. 11. Wall section designed in heat transfer model [56].

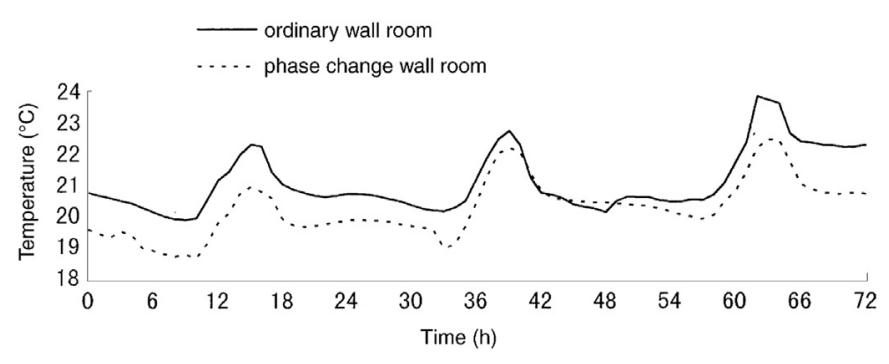

Fig. 12. Indoor air temperature of ordinary wall room and PCM room [57].

authors concluded that DSC results can be used to predict the performance of a full-scale PCM wallboard installation. Similarly, in the study done by Rudd [59] a completed DSC testing on PCM wallboard made up of 25\% PCM was carried out and results showed a melting temperature of $24.9{ }^{\circ} \mathrm{C}$ and thermal storage capacity of $22.26 \mathrm{~J} / \mathrm{g}$. Experiments done at room scale resulted in a thermal storage capacity of $24.2 \mathrm{~J} / \mathrm{g}$. The author concluded that these thermal storage values were not sufficient in order to obtain economic feasibility.

An investigation into the incorporation of gypsum plaster with salt hydrate, $\mathrm{CaCl}_{2} \cdot 6 \mathrm{H}_{2} \mathrm{O}$, was carried out in a full scale experiment and verified by a mathematical simulation [60]. The salt hydrate has a melting range of $25.5{ }^{\circ} \mathrm{C}$ to $27{ }^{\circ} \mathrm{C}$. Two test rooms were constructed, one with salt hydrate plaster wall and the other with conventional gypsum plaster. The study found air temperature of the room with PCM gypsum walls maintained lower daily temperatures and improved the thermal performance of the walls. A maximum temperature reduction of up to $4{ }^{\circ} \mathrm{C}$ could be obtained with the use of PCM walls.

Liu and Awbi [61] conducted a full-scale experiment of PCM boards under natural convection. DuPont Energain panels with $60 \%$ microencapsulated paraffin were positioned on the inner surface of one wall surface of the chamber (wall 5) as seen in Fig. 13.

The main chamber was heated up until surface wall temperatures exceeded PCM melting point, $21.7{ }^{\circ} \mathrm{C}$ and was then cooled down by natural convection or an air handling unit. The peak heat flux density found without PCM was $11.57 \mathrm{~W} / \mathrm{m}^{2}$ and with PCM was $25.8 \mathrm{~W} / \mathrm{m}^{2}$ which showed a $100 \%$ increase on the wall with PCM thus removing heat from the chamber and cooling chamber walls.

A full scale experimental investigation into a PCM copolymer composite wall in three different experimental climates was carried out by Kuznik and Virgone [62], as seen in Fig. 14. The same commercial product tested (ENERGAIN ${ }^{\circledR}$ ) in the previous study was used. An air guard, climatic chamber and solar simulator were used to imitate environmental conditions (Fig. 14).

The air temperature and wall temperature fluctuations were

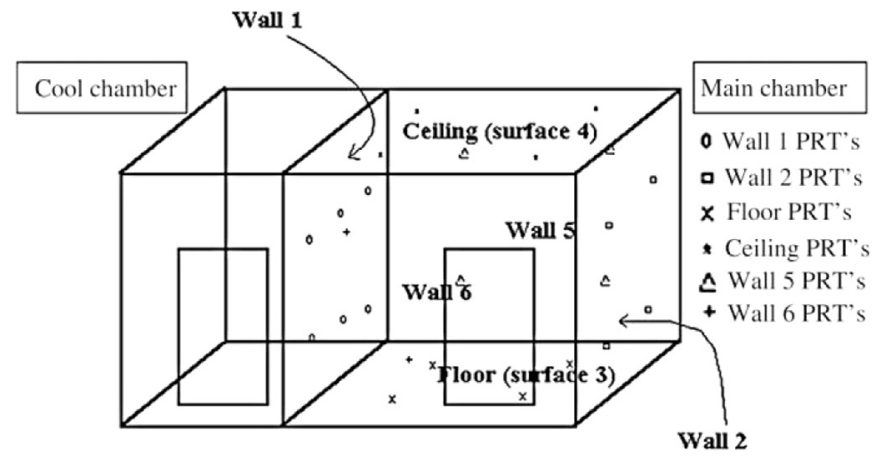

Fig. 13. Experimental set-up [61]. 


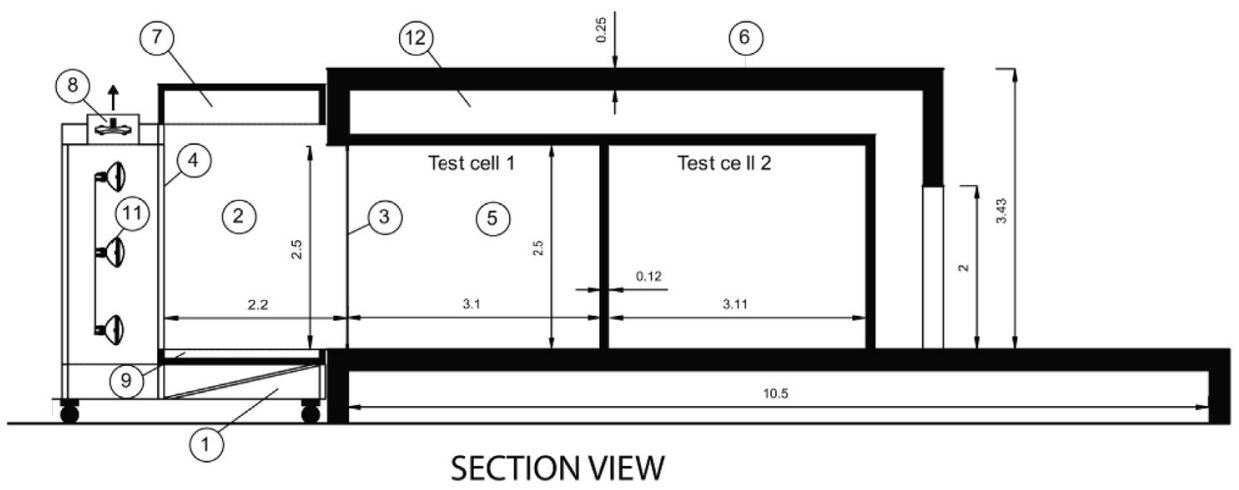

1 cooling unit; 2 climatic chamber; 3 simple glazing; 4 protection glass of the solar simulator; 5 test cell; 6 concrete; 7 air blowing plenum; 8 solar simulator's heat removal ventilators; 9 air extraction plenum; 10 HVAC unit of the thermal guard; 11 solar s imulator; 12 thermal guard. (Metric units)

Fig. 14. Schematic set-up of copolymer composite wall experiment [62].

reduced with PCM. The PCM tested allowed for a decrease of $4.2^{\circ} \mathrm{C}$ of the maximum room air temperature. Summer, mid-season and winter have reported decrement factors of $0.79,0.78$ and 0.73 , respectively. Further testing was conducted on a test cell as in Fig. 15 again with Energain ${ }^{\circledR}$ [63]. PCM was observed to be more efficient when there is a solar heat gain or internal loads. Hysteresis of the material was shown and suggests previous phase changes effect subsequent changes in phase. The most favourable conditions for energy storage and energy release were $22.3^{\circ} \mathrm{C}$ and $17.8^{\circ} \mathrm{C}$, respectively. The experimental results were used to validate a numerical model.

Oliver [64] carried out a comparison study between PCM and several wall materials. It was found the melting rate of the PCM depends on the boundary conditions such as the air velocity and room temperature. As air velocity increases the energy flow into the PCM, a rise of $0.5 \mathrm{~m} / \mathrm{s}$ in air velocity was found to increase the stored energy in the PCM by $14 \%$. A gypsum board containing $45 \%$ by weight of PCM was reported to store 5 times more energy per unit mass than a conventional plasterboard and the same amount of energy than a brick wall of $12 \mathrm{~cm}$ thick.

Heim and Clarke [65] completed a numerical simulation of a

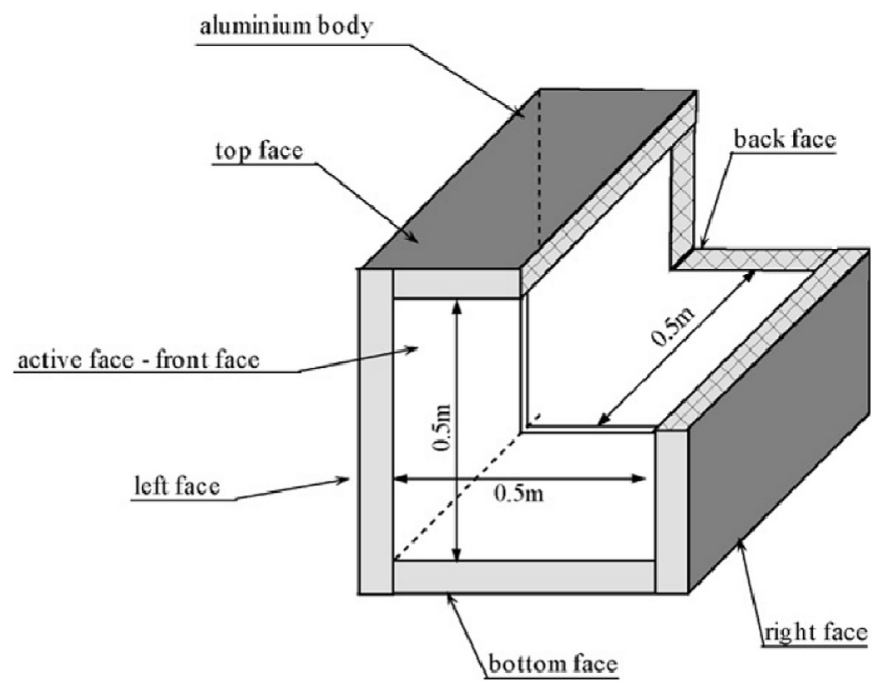

Fig. 15. Test cell which was experimentally tested [63]. passive solar building, incorporating PCM-impregnated gypsum plasterboard as internal room lining. The wall surface temperature allows for $0.5-1{ }^{\circ} \mathrm{C}$ temperature difference with and without PCM as seen in Fig. 16. This is due to the wide temperature range in comparison to the daily zone temperatures. A variation of PCM melting temperatures were investigated and it was found a that a melting temperature of $21^{\circ} \mathrm{C}$ and $24^{\circ} \mathrm{C}$ were optimum as they could absorb and release energy during 6 months of the year.

Mandilaras et al. [66] experimentally investigated the incorporation of gypsum wallboard with PCM (BASF-Micronal ${ }^{\circledR}$ melting point $23^{\circ} \mathrm{C}$ ) in a two storey dwelling in Greece. Similar to previous findings the PCM was only useful between the months of September to June, as July and August had recorded temperatures above the solidification point deactivating the PCM. The optimal melting temperature was also studied in PCM-gypsum plates assessed in a model of a passive house in Beijing, China [67]. Under

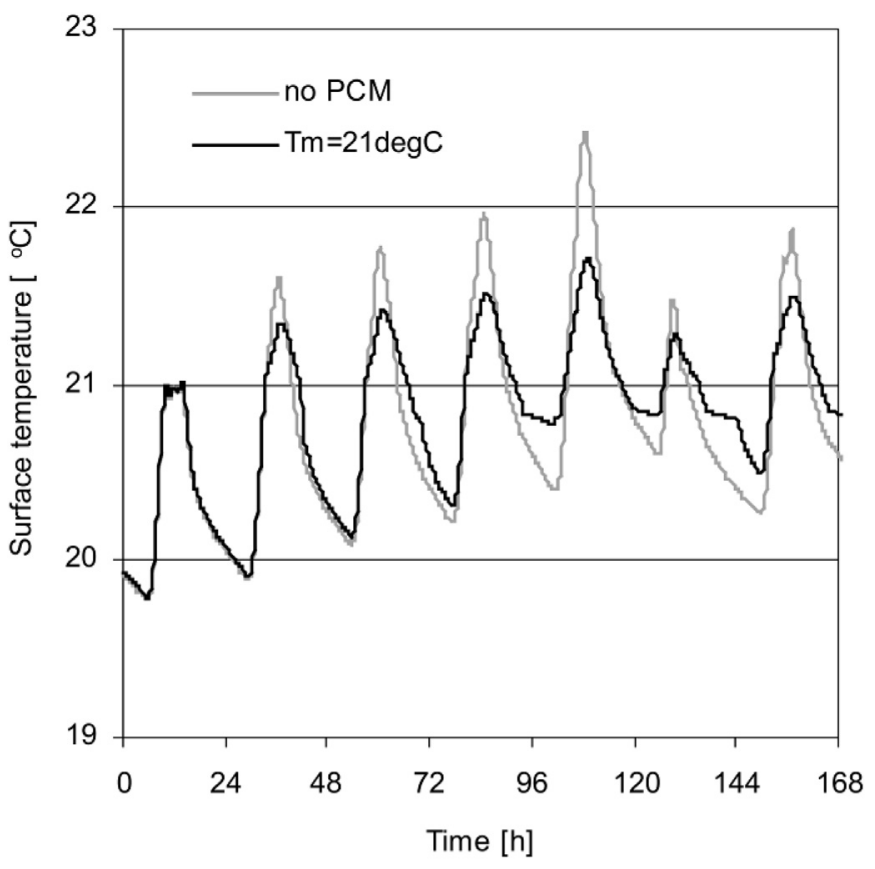

Fig. 16. Temperature fluctuation on wall surface with and without PCM [65]. 
the studied conditions it was found an optimal melting temperature of $21^{\circ} \mathrm{C}$ as this maintains higher daily minimum temperature and reduces the range between day and night. A narrow phase transition zone was suggested to further reduce indoor temperature swing and improve thermal comfort due to larger thermal storage, as seen in Fig. 17.

Neeper [68] examined the thermodynamics of a conceptual model of PCM wallboard that was subjected to the daily variation of room temperature and no direct solar gain. Guidelines were presented for domestic implementation of PCM wallboards. The effect of diurnal storage of $10 \%$ and $20 \%$ PCM of an interior wall was simulated, as in Fig. 18.

The results showed the maximum daily energy storage occurs when the PCM melt temperature equals the average wall temperature. The thermal storage is at a maximum when the phase transition width is narrow, i.e. $\mathrm{W}=0.5^{\circ} \mathrm{C}$. The melting temperature of the PCM depends on the average room melting temperature when considering internal PCM wallboards. Further results are presented on exterior wallboards. It was shown PCM wallboard has little effect on the net heat conducted unless the thermal storage affects the average room temperature.

A numerical analysis on a PCM wallboard $17 \mathrm{~m}$ long, $13 \mathrm{~m}$ wide and $3 \mathrm{~m}$ high was conducted in TRNSYS by Stovall and Tomlinson [69]. The paraffin n-octadecane with a melting point of $23{ }^{\circ} \mathrm{C}$ was incorporated with common wallboard. The model was completed for a typical Boston winter and Nashville and Miami summers. It was reported PCM wallboards can improve load management within the building. However, this is dependent on internal thermal control system of the building, PCM melting temperatures and PCM placement. It was suggested integrating two PCM with varying melting temperatures in one structure could improve the performance of the wallboards.

Peippo et al. [70] incorporated a PCM wall with a hypothetical passive solar building in a numerical model to evaluate its thermal performance in Helsinki, Finland and Madison, USA. The results suggested a PCM melting temperature of $1-3{ }^{\circ} \mathrm{C}$ above room temperature would yield optimal heat storage results. Fatty acids are recommended as they can be mixed to obtain the required melting temperature. It was shown energy savings of $10-15 \%$ could be made if the PCM wall was positioned in a direct gain room in a residential dwelling. The thickness of the PCM was also studied, as in Fig. 19. It was found $10-15 \mathrm{~mm}$ was the optimal thickness of PCM.

Kuznik et al. [71] monitored a renovated office building which

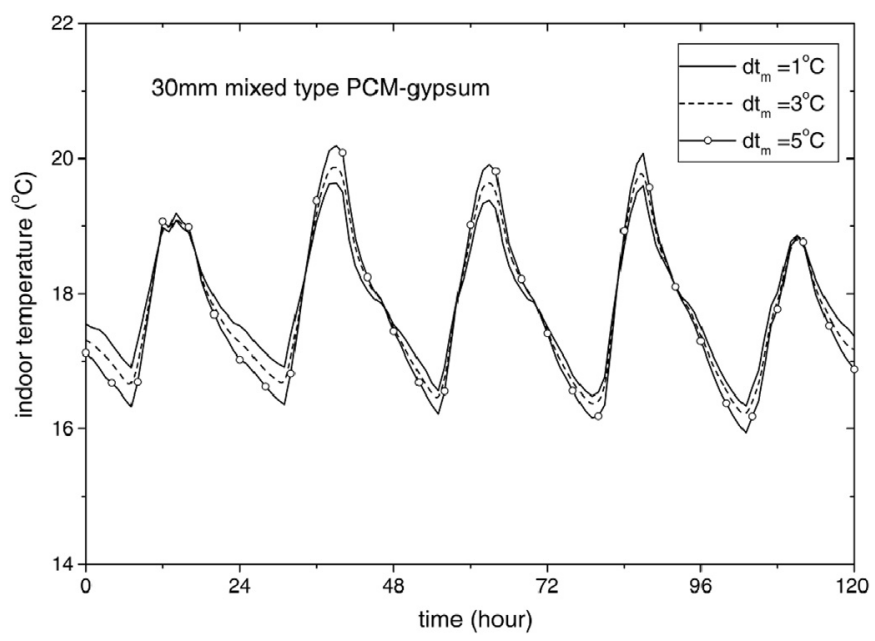

Fig. 17. Indoor temperature vs. phase transition zone of PCM gypsum wallboard [67] was altered to include two rooms, one with PCM wallboards in lateral walls and ceiling and another identical room with no PCM wallboards. The building was monitored for a year. It was found PCM wallboards can be efficient if the air temperature within the room varies within the melting and solidification range of the PCM. The maximum air temperature of the room without PCM was found to be $2.2{ }^{\circ} \mathrm{C}$ higher than that with $\mathrm{PCM}$, thus improving thermal comfort of the occupant. Further full scale investigation was carried out on PCM wallboards in a cell of dimensions $5 \mathrm{~m} \times 3.3 \mathrm{~m} \times 2.8 \mathrm{~m}$ with a $1.5 \mathrm{~m} \times 1.5 \mathrm{~m}$ window by Kuznik et al. [72]. The PCM tested was a product of DuPont which was made up of $60 \%$ of microencapsulated PCM with a melting temperature of $22{ }^{\circ} \mathrm{C}$ (Fig. 20). It was found the PCM reduced temperature fluctuations in the room, with a maximum decrease of $4.4^{\circ} \mathrm{C}$ recorded for summer climatic conditions which were simulated using a solar simulator and temperature control unit.

Discharging of the PCM can be seen when the temperature of the room is at a minimum thereby enhancing the thermal comfort. The PCM walls were found to enhance thermal cooling as they were at a lower temperature than without PCM. It was reported the $5 \mathrm{~mm}$ of PCM wallboard had twice the available energy storage as that of an $8 \mathrm{~cm}$ concrete layer.

The Passivhaus benefits from offsite construction and structural insulation panels tend to decrease thermal mass. Colclough et al. [73] undertook computer simulations of PCM plasterboards used in a Passivhaus in a number of climates. The building was simulated using the climates of Athens, Madrid, Paris and Belfast. Wallboards with melt temperatures of $23{ }^{\circ} \mathrm{C}$ and $26{ }^{\circ} \mathrm{C}$ were analysed. Free cooling was achieved in sites except Belfast; see Fig. 21 which illustrates the cooling effect for Paris. The $23{ }^{\circ} \mathrm{C}$ board was not effective in Athens as the wallboard became saturated. The $26{ }^{\circ} \mathrm{C}$ wallboard provided significant passive cooling bringing temperature below Athens for 403 h, 341 h in Madrid and 140 h in Paris. The $23{ }^{\circ} \mathrm{C}$ board did not allow for recharging for part of the time in Athens are the temperature did not drop low enough at night. Hence the wallboards modulate the temperature profile of the internal space with the best results in the Mediterranean countries. For Belfast the climate did not require the activation of either of the temperature wallboards, however in the winter the wallboard modulated night time temperatures, decreasing the temperature drop overnight, and hence reducing the total heating demand to raise the space temperature to comfort levels in the morning. However, basing an installation of wallboards on this latter effect would be financially uneconomic. The work demonstrated that the choice of temperature for the PCM was dependent upon climate and building.

\subsubsection{Sandwich panel}

Carbonari et al. [74] presented a numerical analysis of sandwich panels for prefabricated walls containing PCM. The numerical simulation was based on a finite element model and was found to be in agreement with experimental results and could be used as a tool for designers. The experimental set up is shown in Fig. 22.

Four panel types were tested, each with varying air layer and PCM thickness. The PCM used had a melting point of $32{ }^{\circ} \mathrm{C}$. Results found an air layer between the PCM and the external metal finishing layer is capable of improving the performance of sandwich panels containing PCM.

Medina et al. [75] presented a study on a new type of panel wall, phase change material structural insulated panel (PCMSIP) as in Fig. 23(b). Two identical test houses were constructed; House A was used as a control using conventional building materials and House B contained PCMSIPS, as in Fig. 23(a). The PCM integrated with the structural insulating panels had a phase change range of $25^{\circ} \mathrm{C}-32.5^{\circ} \mathrm{C}$ and a heat storage capacity of $131 \mathrm{~kJ} / \mathrm{kg}$. 

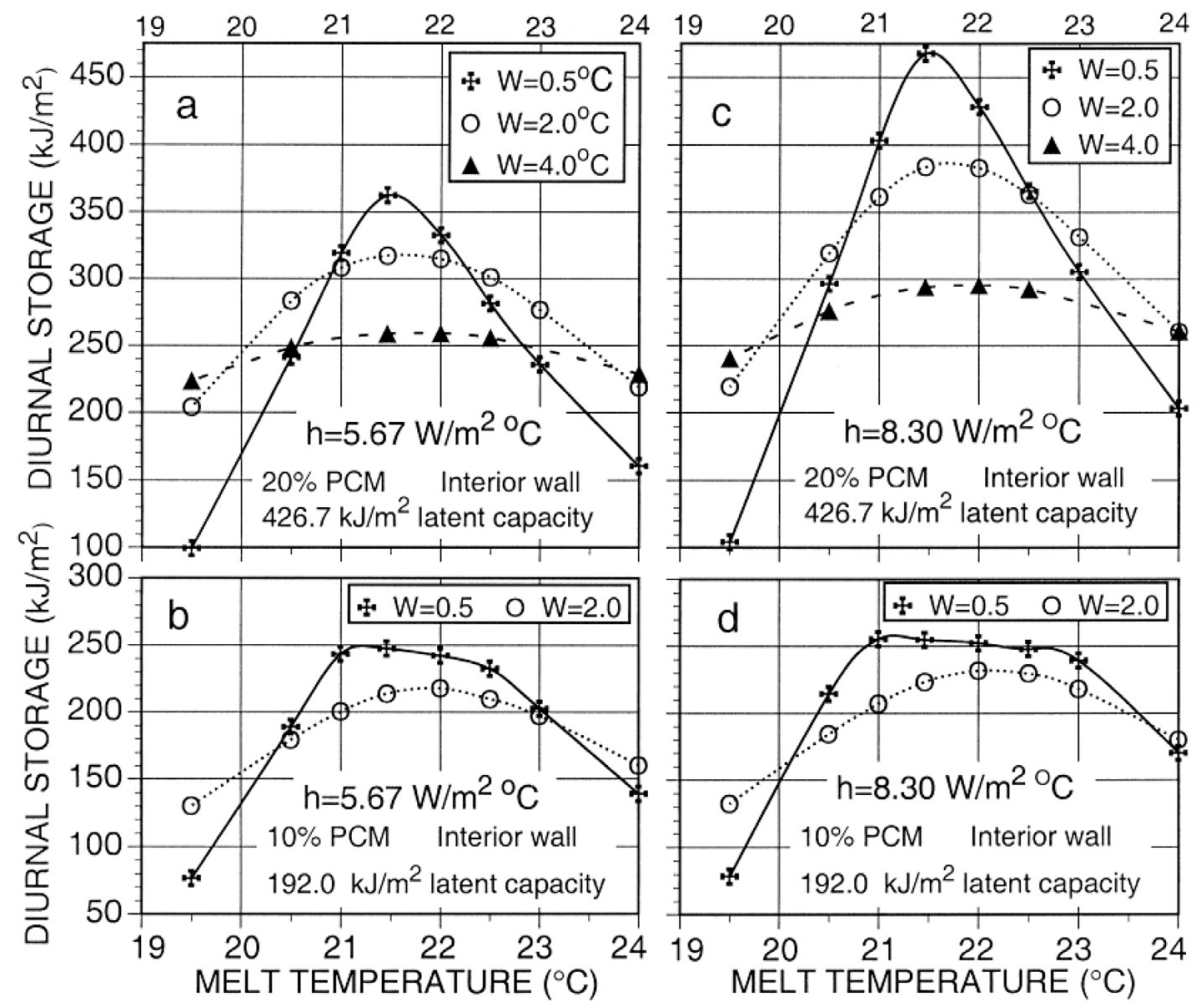

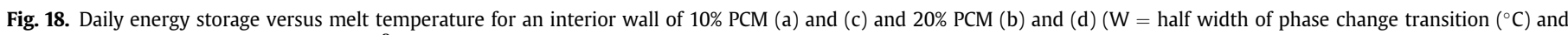
$\mathrm{h}=$ surface heat transfer coefficient $\left.\left(\mathrm{W} / \mathrm{m}^{2}{ }^{\circ} \mathrm{C}\right)\right)$ [68].

PCMSIP was integrated with 10\% PCM based on sheath weight. It was shown on average, the peak heat flux reduced by $37 \%$ and $62 \%$ for $10 \%$ and $20 \%$ PCM, respectively, compared to the control house. The amount of heat transferred through the PCMSIPS compared to House A were $33 \%$ and $38 \%$ for concentrations of $10 \%$ and $20 \%$, respectively.

Konuklu and Paksoy [76] incorporated PCM with sandwich panels and tested them under Mediterranean climatic conditions in Adana, Turkey. Two types of microencapsulated powdered paraffin PCM were placed on aluminium foil in layers to produce the panels. The PCM had melting points of $26^{\circ} \mathrm{C}$ and $23^{\circ} \mathrm{C}$, respectively. The

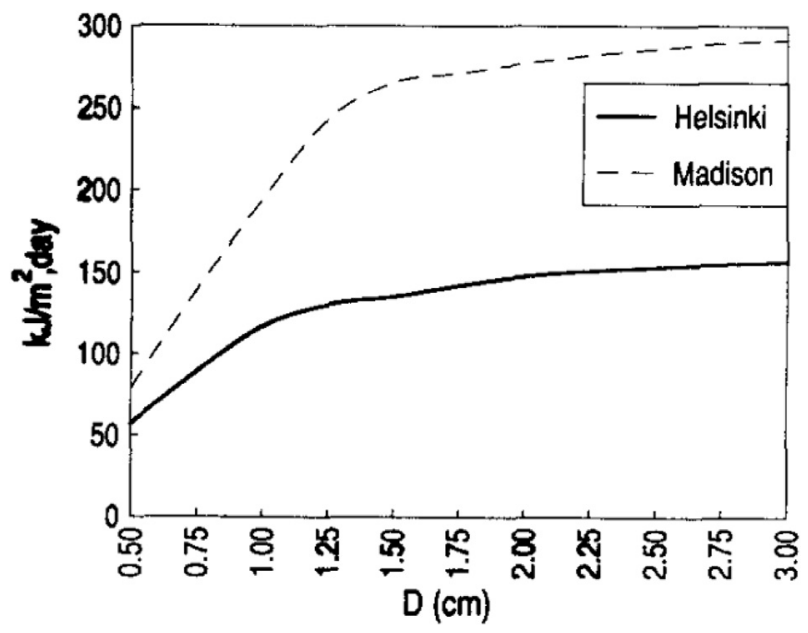

Fig. 19. Average night time heat flow $\left(\mathrm{kJ} / \mathrm{m}^{2}\right.$ day) from $\mathrm{PCM}$ wall during October-March at optimal transition temperature, as a function of panel thickness D [70]. panels were tested in prefabricated cabins. In summer a maximum average temperature reduction of $2.5^{\circ} \mathrm{C}$ was found and a summer cooling load reduction of $7 \%$ with the PCM panels. In winter, the maximum temperature increase achieved was $2.2{ }^{\circ} \mathrm{C}$. It was

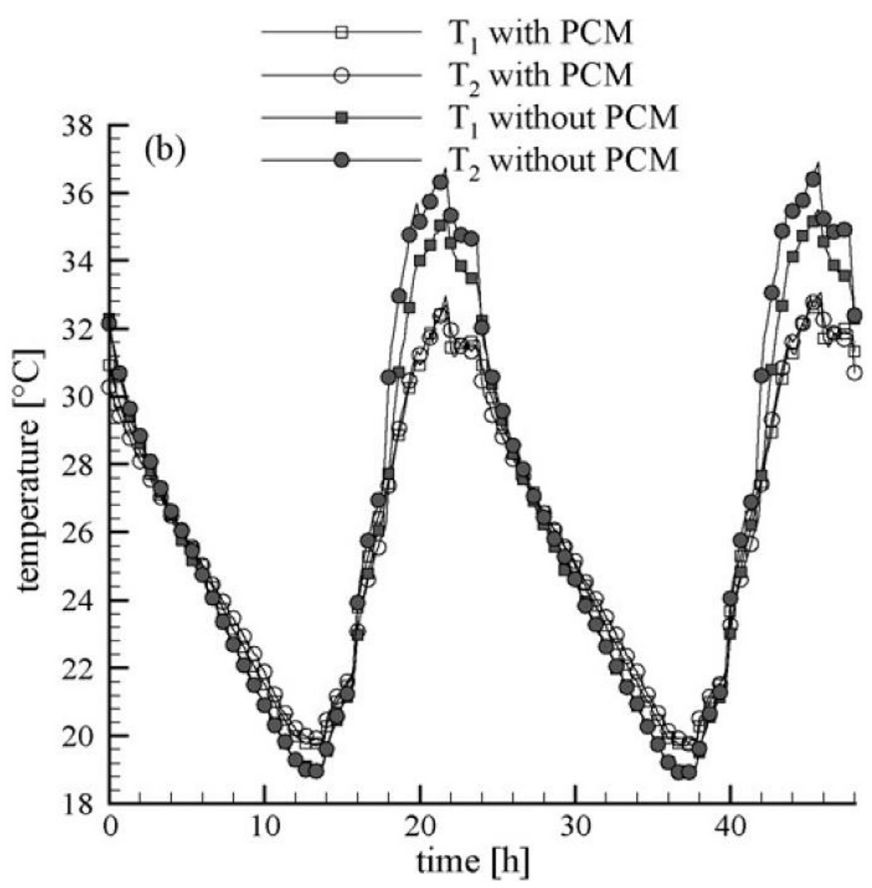

Fig. 20. Temperature within the experimental cell at height $\mathrm{T} 1=0.85 \mathrm{~m}$ and $\mathrm{T} 2=1.7 \mathrm{~m}[72]$. 


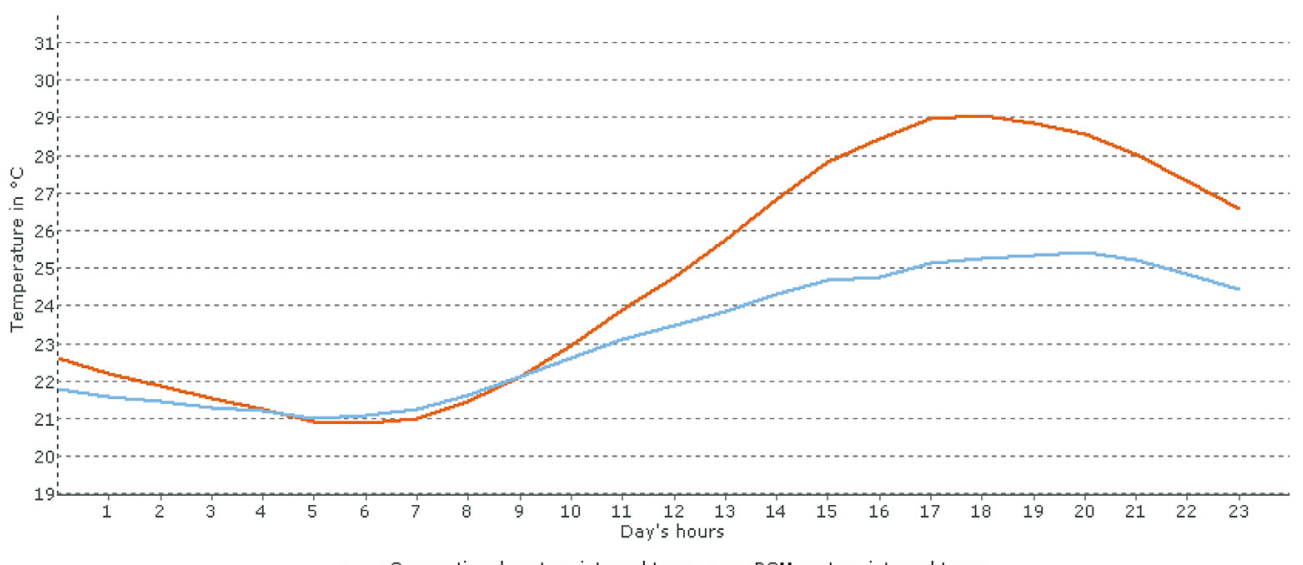

Fig. 21. Day of Greatest PCM Effect for Paris, France for $23{ }^{\circ} \mathrm{C}$ PCM wallboard (12th July) [73].

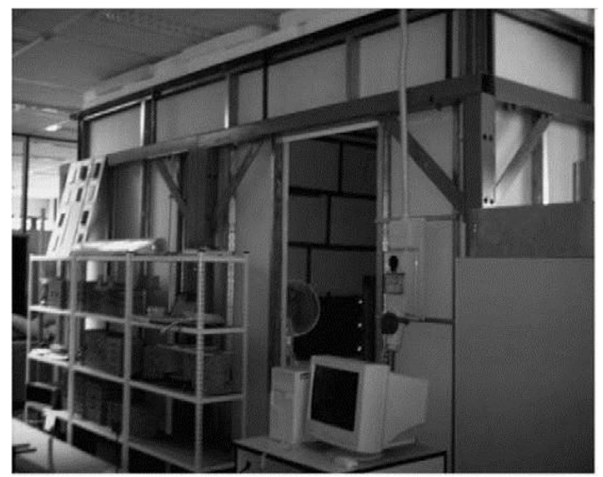

(a)

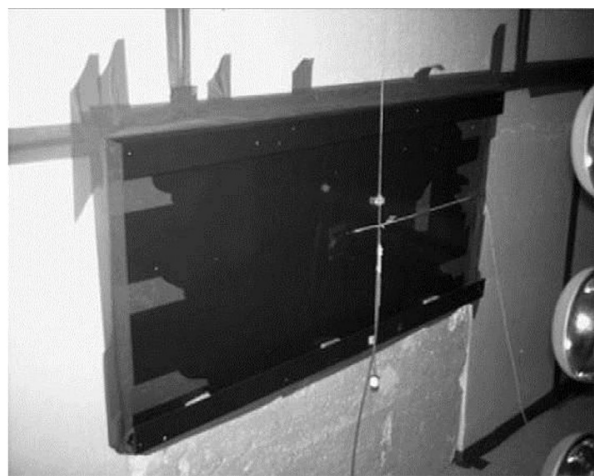

(b)

Fig. 22. (a) Testing cell (b) Panel integrated into the wall [74].

recommended to use PCM within the range $24-26^{\circ} \mathrm{C}$ for a continental climate.

Castellón et al. [77] presents three methods to integrate microencapsulated PCM in sandwich panels. In Case 1, the PCM was added by mixing the microencapsulated PCM with one of the components of the polyurethane. In Case 2 PCM was added a step before the polyurethane was injected between the metal sheets, while in Case 3 PCM was added once the polyurethane was included between the metal sheets. Results proved that Case 1 was the best option as the distribution of PCM was homogenously spread throughout the panel. An increase in thermal conductivity of the panel with PCM was found due to an increase in solids. The adhesion between the metal sheets and polyurethane foam passed the standard. However, this was not the situation for Case 2 and Case 3.

\subsubsection{Macro-encapsulated in plates or bags}

Castell et al. [78] studied the thermal and energetic performance of several house-like cubicles built with conventional brick and alveolar brick systems (as shown in Fig. 24). PCM was incorporated in macro-encapsulated form having RT-27 aluminium plates [79] in the conventional brick cubicles and SP-25 in the alveolar brick

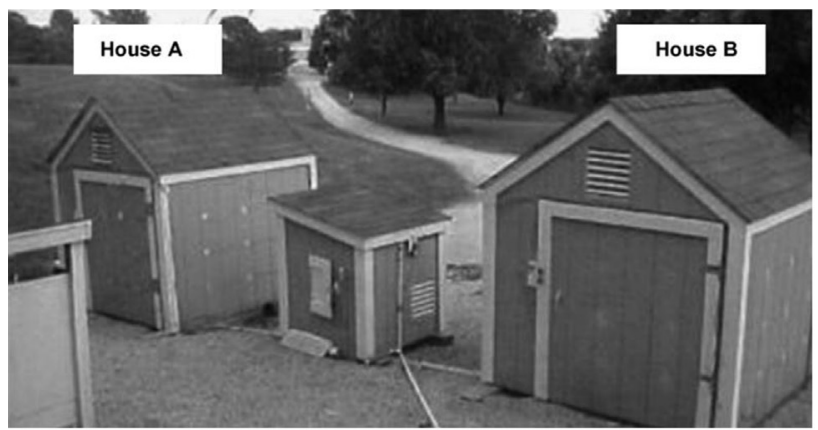

(a)

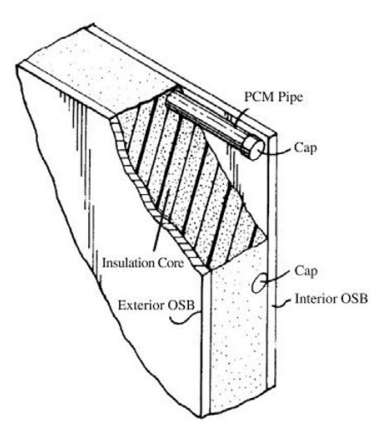

(b)

Fig. 23. (a) Full-scale experimental set-up (b) PCMSIP cross-section [75]. 


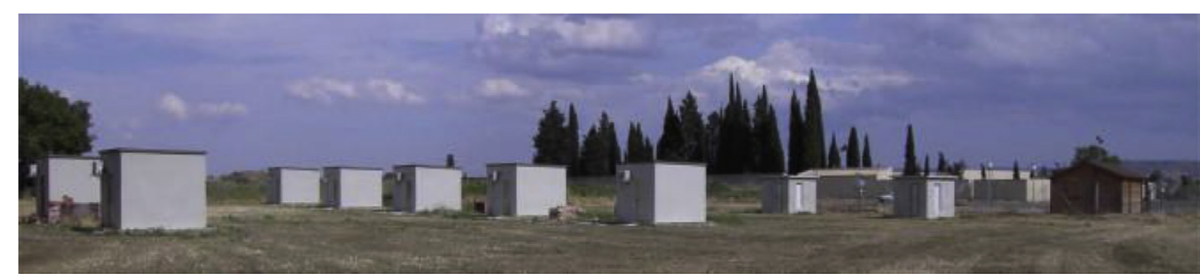

Fig. 24. Experimental set-up in Puigverd de Lleida (Spain) [78].

cubicles as a passive cooling system. The energy consumed by the heat pump of the cubicles which was set up at a constant temperature was compared. The results showed that the conventional brick cubicles which included PCM achieved a maximum energy consumption reduction of $15 \%$ under summer conditions, compared to the one without. On the other hand, the alveolar brick cubicle with SP-25 reached a maximum of $17 \%$ of energy savings compared with the one without.

Zhang et al. [80] suggested several benefits of using macroencapsulated PCM in building structures. The idea was to overcome the problems of PCM embedded systems, which demonstrate many advantages in energy savings but two main problems: durability of PCM-impregnated gypsum boards and low fire rating. A frame wall which incorporated PCM macro-encapsulated was tested. The results obtained show a reduction on the cooling load with the inclusion of $10 \%$ and $20 \%$ of PCM, about $8.6 \%$ and $10.8 \%$ respectively.

Previously, in 1997, Ismail and Castro [81] integrated PCM (a mixture of two commercial grades of glycol) as a thermal barrier in brick walls and roofs typical of Brazilian construction. Side by side experiments were performed to compare the behaviour of the new concepts with conventional ones and to validate a numerical model. Results showed the effectiveness of PCMenhanced walls in maintaining constant and stable indoor air temperatures and proved the potential for load reduction and load shifting.

A major problem when designing passive PCM systems for buildings is the selection of the phase change temperature. It is not possible to use a single PCM suitable for yearly operation due to weather changes between seasons. Pasupathy and Velraj [82] studied a double layer PCM concept to achieve year round thermal management of buildings (Fig. 25). A numerical model of a roof

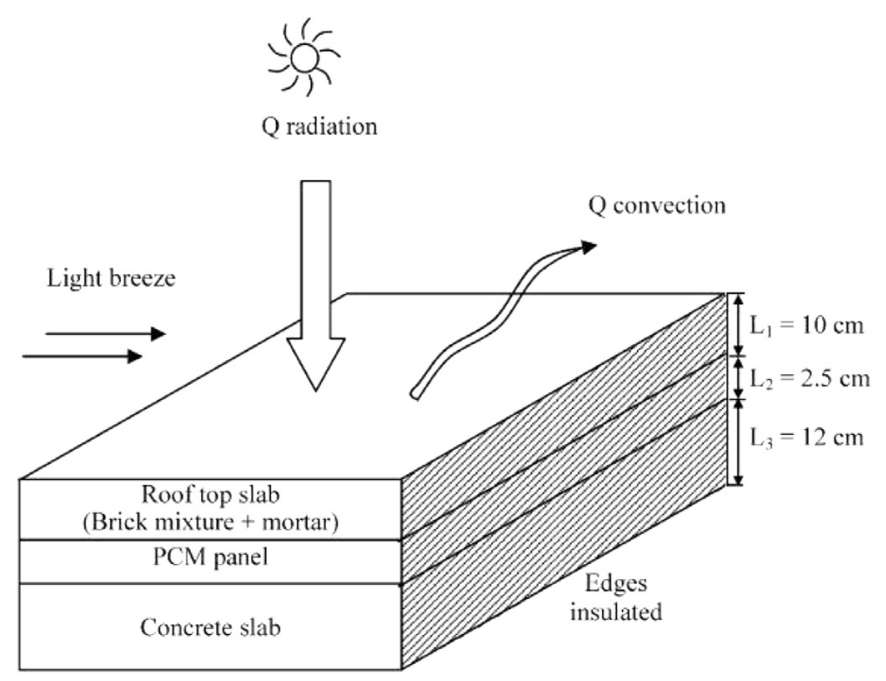

Fig. 25. PCM incorporated in a roof system [82]. incorporating one layer of macro-encapsulated PCM was experimentally validated. This model was then used to simulate the behaviour of a system with a double layer of macro-encapsulated PCM. The PCM used was an inorganic salt hydrate (48\% $\left.\mathrm{CaCl} 2+4.3 \% \mathrm{NaCl}+0.4 \% \mathrm{KCl}+47.3 \% \mathrm{H}_{2} \mathrm{O}\right)$ melting at $32.8{ }^{\circ} \mathrm{C}$, encapsulated in a stainless steel panel of $2 \times 2 \mathrm{~m}$ and $2.5 \mathrm{~cm}$ thickness. Numerical results showed that a double layer of PCM incorporated in the roof is a good system for reducing the indoor air temperature fluctuations during different seasons of the year.

In 2008, Alawadhi [83] studied numerically the behaviour of a PCM-brick composite for hot climates (Kuwait city). The PCM was introduced in the cylindrical holes of the bricks (Fig. 26), and different amounts, PCM materials and locations were studied. The model was finite element two-dimensional and used the effective heat capacity to simulate the PCM. To evaluate the thermal effectiveness, the internal heat flux of the PCM-brick and the conventional brick were compared. The results showed a reduction of the heat flux up to $24.2 \%$ when using the best configuration. An increase on the PCM quantity resulted in better savings, being the best location in the centreline of the brick.

In a later work, de Gracia et al. [84] and Castell et al. [85] performed a Life Cycle Assessment of two construction systems (conventional brick and alveolar brick systems) including macro-encapsulated PCM. Results showed that, for a life span of 50 years, the incorporation of PCM did not significantly affect the environmental impact. An extended use of the PCM, either by taking advantage of the phase change during longer periods of the year or by increasing the life span of the building, could result in an increased effect of the PCM. The analysis also highlighted that salt hydrates had less environmental impact than paraffin.

Later on, Silva et al. [86] studied a similar concept at laboratory scale by incorporating the PCM (RT18) in steel macrocapsules

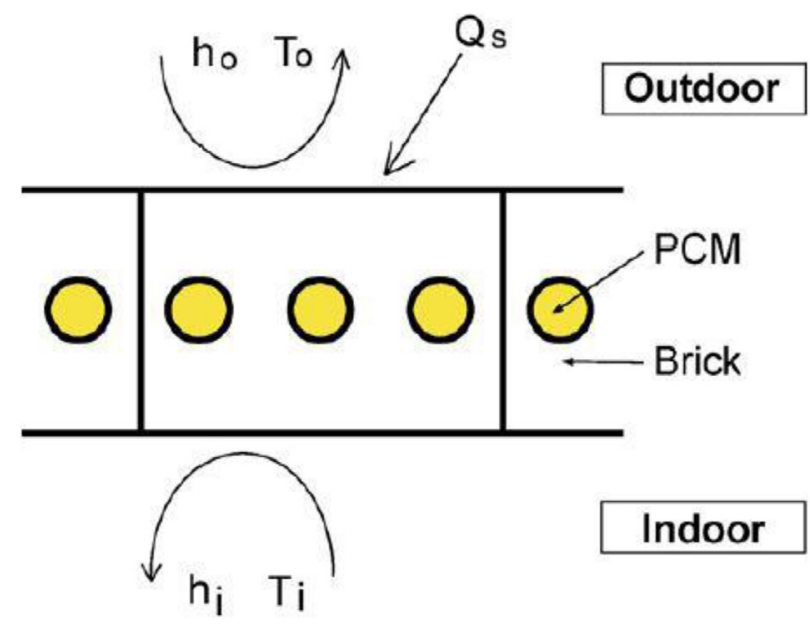

Fig. 26. Brick-PCM system [83]. 


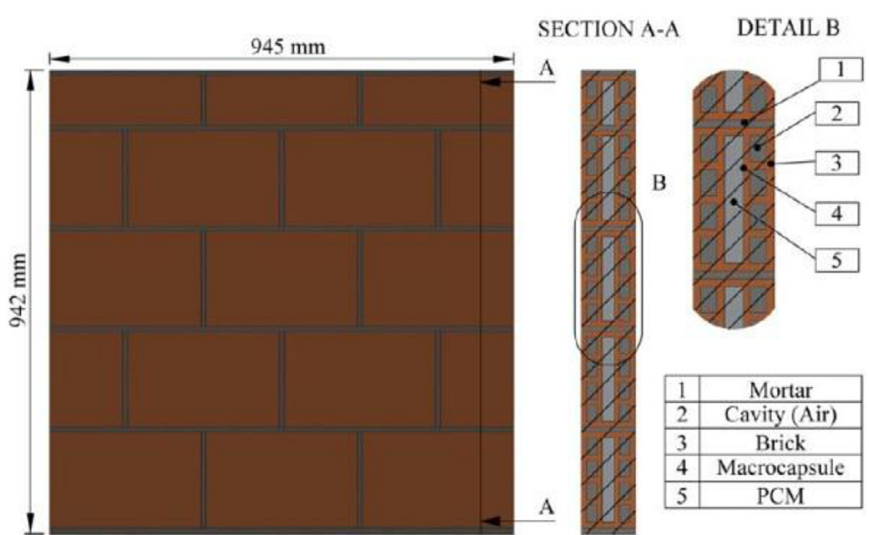

Fig. 27. Macro-encapsulated PCM inserted inside brick holes [87].

( $30 \times 17 \times 2.8 \mathrm{~cm}$ and $0.75 \mathrm{~mm}$ mean thickness) inserted into brick voids (Fig. 27). Walls were built using typical horizontally hollowed clay bricks $(30 \times 20 \times 15 \mathrm{~cm})$. A reference case without PCM was compared with the newly developed PCM sample. Both samples were tested in a climatic chamber, where in one chamber external boundary conditions were imposed and in the other chamber internal responses were registered. Results showed a reduction of the temperature swing, from $10{ }^{\circ} \mathrm{C}$ in the reference sample to $5{ }^{\circ} \mathrm{C}$ in the PCM sample, and an increase in the time lag of $3 \mathrm{~h}$ when incorporating PCM. Experimental results were also compared to those obtained by a numerical model. Differences between modelling and experiments from 0 to $3^{\circ} \mathrm{C}$ were observed for the air temperature, while differences increased to $1-3.5{ }^{\circ} \mathrm{C}$ for the PCM. Further experiments from Vicente and Silva [87] determined that the combination of PCM and external insulation (10 $\mathrm{cm}$ of XPS) resulted in thermal amplitude reductions of $80 \%$ compared with the sample without PCM.

Macro-encapsulated PCM incorporated in a concrete roof was numerically studied by Allawadhi and Alqallaf [88]. The model consisted of a concrete slab with vertical cone frustum holes filled with PCM (Fig. 28) in order to take advantage of the latent heat to reduce heat gains during hot weather periods and thus reduce energy demand. Different PCM geometries were proposed, moving from a cylinder to a frustum cone and maintaining a constant PCM volume. Heat flux at the indoor surface of the roof was evaluated as an effectiveness indicator. Results showed that conical geometry achieved the best thermal effectiveness, reducing heat flux by up to $39 \%$.

Cerón et al. [89] designed a new pavement incorporating PCM (Fig. 29) to act as a passive thermal conditioning system (patent $n^{\circ}$. ES2333092 A1 [90]). The system was based on tiles of $660 \mathrm{~mm} \times 660 \mathrm{~mm} \times 52 \mathrm{~mm}$ dimensions, consisting of 4 pieces of pure clay stoneware $(20 \mathrm{~mm})$, a top metal sheet $(3 \mathrm{~mm})$, a metal container ( $32 \mathrm{~mm}$ ) which contained $4.8 \mathrm{l}$ of paraffinic mixture, and a layer of thermal insulation $(22 \mathrm{~mm})$, which in turn served as acoustic insulation for the framework. The metallic container consisted of a low metal tray formed by 41 honeycomb structured stamps. ACUAL 20 (paraffinic composition) was used as PCM with nominal melting temperature at $20^{\circ} \mathrm{C}$ and nominal solidification temperature at $13.5^{\circ} \mathrm{C}$. The tiles were tested in a small test house called "Magic Box", where both PCM and none-PCM tiles were subjected to solar radiation. Surface temperatures of tiles showed that those with PCM presented more stabilized values than those without PCM. This new product could be used for refurbishing of buildings, but it has to be limited to the areas with direct incident solar radiation.

In 2013, Kong et al. [91] developed a new kind of macro- (a)

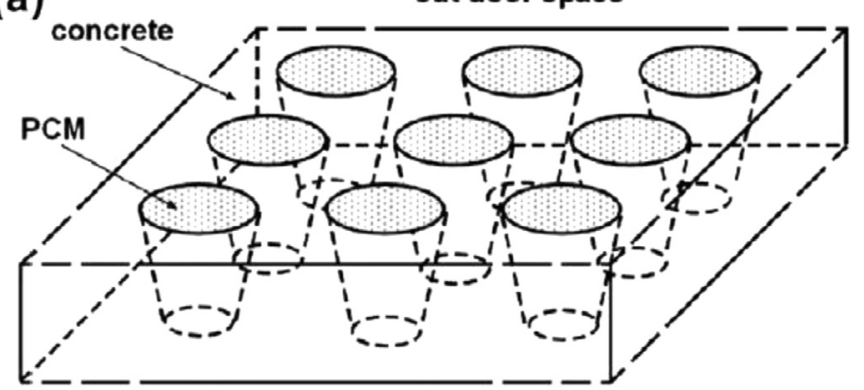

in door space

(b)

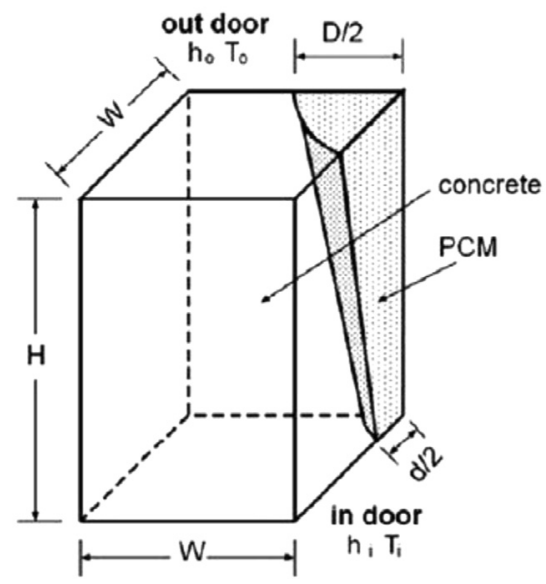

Fig. 28. (a) Schematic representation of the roof with holes filled with PCM and (b) the computational domain and important geometric parameters and boundary conditions [88].

encapsulated PCM called PCM panel and performed very similar experimental work to [89], although focussing only on temperatures. The panel consists of two aluminium sheets filled with PCM. Inside the panel, a set of fins acted both as a heat transfer enhancer and as a structural support. This concept was experimentally tested for summer conditions in two full size rooms built with brick, one containing capric acid (CA, with melting temperature of $30.2{ }^{\circ} \mathrm{C}$ ) installed on the outer surface of the room and another one containing a mixture of capric acid and 1-dodecanol (CADE, with melting temperature of $26.5^{\circ} \mathrm{C}$ ) installed on the inner surface of the room. Another room without PCM was also built as a reference. Tests were performed for free-floating temperature, open windows and door at night, and forced ventilation at night. Results showed a decrease of the peak temperature, a reduction of the temperature fluctuations and an increase of the thermal inertia, especially for the case where PCM was located in the inner surface of the walls.

\subsubsection{Micro-encapsulated PCM in a clayboard}

Colclough [92] studies the performance of a clay wallboard, into which a $23^{\circ} \mathrm{C}$-microencapsulated PCM, $30 \%$ by weight, was added

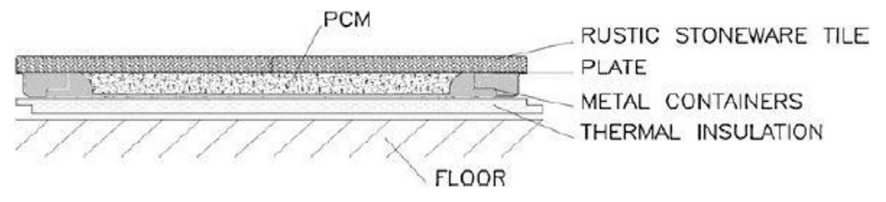

Fig. 29. Tile with macro-encapsulated PCM [89]. 
during the wallboard manufacture. The wallboards were mounted on the internal walls of a test cell at Ulster University, which was then subject to illumination for $6 \mathrm{~h}$ by a $28 \mathrm{~kW}$ solar simulator. With the test cell in its normal configuration the internal temperature raised over $28{ }^{\circ} \mathrm{C}$ within $5 \mathrm{~h}$ of the experiment. The PCMclayboard modulated the temperature, with the internal temperature of the test cell kept below $26^{\circ} \mathrm{C}$ during the duration of the $6 \mathrm{~h}$ test. The overall performance of the wallboards decreased over time, and a DSC sample provided a specific heat of melting considerably lower than the manufacturer figures. Samples of the wallboard were sent to the University of Lleida where they were analysed using a scanning electron microscope. The researchers at Lleida reported some rupturing of the microcapsules containing the PCM, see Fig. 30.

The cause of the rupturing was not determined, however clay particles are angular and compression applied to the wallboards during manufacturer may have led to a proportion of the microcapsules being broken. The long-term performance of such clayboards may be subject to degradation should rupturing of the microencapsulation lead to the leakage of PCM from the wallboard. This demonstrates that when microencapsulated PCMs are added to a material, the effect of manufacturing processes and the physical nature of the bulk material on the microcapsule need to be considered.

In general terms, studies presented in this section 4.2 do not reflect clear conclusions since results are quite dispersed and not comparable. For this reason, authors summarized in Table 4 the most relevant aspects of the papers reviewed related to PCM incorporated as a new layer in buildings.

To sum up incorporation of PCM in gypsum plasterboards is mainly done around $25 \%$ in weight except in the commercial product of DuPont which achieved significantly better results by the addition of $60 \mathrm{wt} \%$.

It also can be reported from most of the studies that the selection of the phase change material must involve careful consideration of the requirements of the application. Such as PCM embedded in sandwich panels which need a phase change temperature above the comfort range temperature, due to its use as a passive cooling protection.

For space heating and cooling of a building, the local climate and seasonal variations in temperature should be also taken into

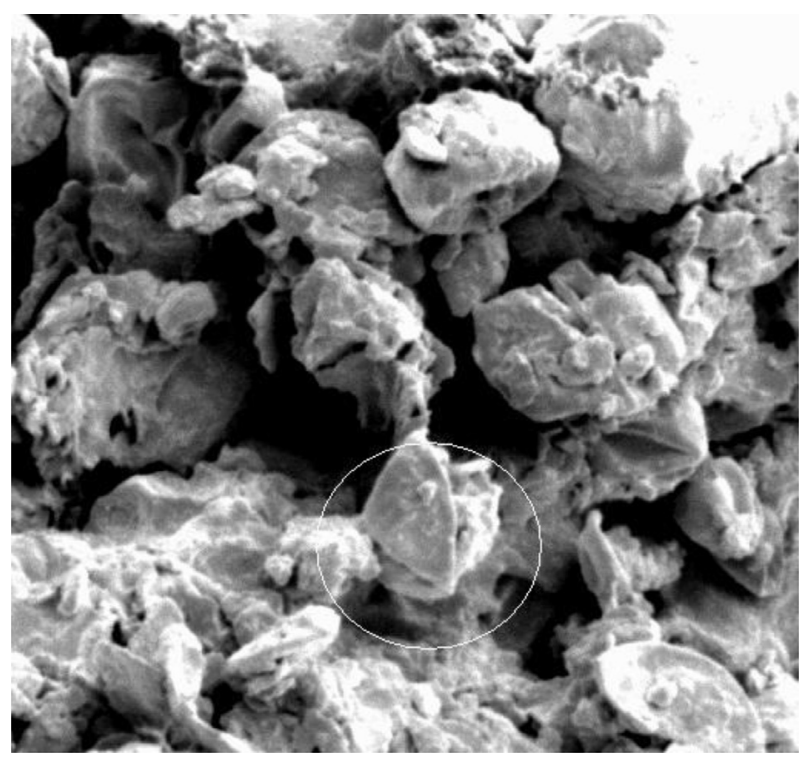

Fig. 30. Electron microscope image of EBB clay/PCM wallboard sample $(\times 2000)$ [92]. account, as some macro-encapsulated studies mentioned. Several ways of including macro-encapsulated PCM in building envelopes were presented such as inside hollows of bricks, under the floor lining, or even inside the ceiling component. And also phase change temperature in these applications was oscillating between $18{ }^{\circ} \mathrm{C}$ and $37^{\circ} \mathrm{C}$ depending on if the PCM was acting as an external protection or a thermal inertia addition to the inner environment.

\subsection{Windows and sun protections}

A sun protection system with integrated PCM was designed and monitored under winter and summer conditions in Germany [93]. The system incorporates the salt hydrate Delta ${ }^{\circledR} \mathrm{Cool}-28$ which has a melting range of $26^{\circ} \mathrm{C}-30^{\circ} \mathrm{C}$ and melting enthalpy of $188 \mathrm{~J} / \mathrm{g}$. A $70 \mathrm{~cm} \times 70 \mathrm{~cm}$ sample of the sun protection system was installed in the test facility which consists of two temperature controlled chambers simulating the indoor and outdoor conditions, as shown in Fig. 31.

It was found that the PCM incorporated sun blind rarely exceeded temperatures over $28{ }^{\circ} \mathrm{C}$ compared to common interior sun protection systems which can reach temperatures of up to $40^{\circ} \mathrm{C}$. The solar gain coefficient of the sun protection system is 0.25 for a totally closed blind and 0.3 for slats positioned at $45^{\circ}$, these values are lower than blinds without PCM which have resulted in corresponding solar heat gains coefficients of 0.35 and 0.41 , respectively. The maximum air temperature was reduced by $2{ }^{\circ} \mathrm{C}$ compared to a room with conventional blinds.

An experimental and numerical study was carried out on a double glazed PCM-facade-panel [94]. As PCM are semitransparent, they can be used as daylighting elements. Two systems were installed one with $12 \mathrm{~mm}$ of the paraffin wax RT25 (Rubitherm) and one with $8 \mathrm{~mm}$ of the salt hydrate S27 (Cristopia). Each PCM was encapsulated in a container as shown in Fig. 32. These two PCM along with a third one, L30 (Merek) were investigated computationally.

In the winter performance, it was found that a facade panel with PCM reduces heat losses by $30 \%$ in south orientated facades compared to a facade without PCM. However, solar heat gains were also reduced by about 50\% which compensate the energy balance during the day. On the other hand, in summer period the peak temperatures are delayed into the evening and the cooling load is reduced.

Manz et al. [95] theoretically and experimentally investigated the application of transparent insulation material (TIM) and translucent PCM in an external wall for solar space heating and daylighting. $300 \mathrm{~mm}$ of salt hydrate was integrated with an external TIM wall and tested under Zurich, Switzerland climatic conditions. It was found the PCM provided a positive effect on the solar gains as the energy flows into the building were more evenly distributed. However, backscattering of solar radiation when the PCM was discharged caused reductions of heat gain and loss of light. For a climate such as Zurich, Switzerland a PCM melting temperature of $21^{\circ} \mathrm{C}$ was recommended.

Investigation into composite and PCM glass was carried out by Ismail and Henriquez [96]. The number of glass panels, spacing between the panels, type of filling and colour were among the parameters studied. A model was presented which was validated experimentally. The thickness of the glass and spacing between the double glazing was shown to have relatively little effect on the transmittance of the glass windows. Filling the spacing with PCM was shown to dramatically reduce the transmittance, particularly in the infra-red range compared to filling the double glazing with air, as shown in Fig. 33.

It was also reported the $U$ value decreased with an increase in 
Table 4

Performance and characteristics of the addition of PCM as new layer.

\begin{tabular}{|c|c|c|c|c|c|c|}
\hline & Reference & Type & Application & $\begin{array}{l}\text { Phase change } \\
\text { temperature }\end{array}$ & PCM quantity & Performance \\
\hline \multirow[t]{16}{*}{$\begin{array}{l}\text { Gypsum } \\
\text { plasterboard }\end{array}$} & Scalat et al. [55] & EXP & $\begin{array}{l}\text { Heating } \\
\text { Cooling }\end{array}$ & $\begin{array}{l}20.5^{\circ} \mathrm{C} \text { Melting } \\
18^{\circ} \mathrm{C} \text { Solidification }\end{array}$ & $\begin{array}{l}25.7 \text { wt\% fatty acid } \\
\text { esters mixture }\end{array}$ & $\begin{array}{l}\text { - Room temperature maintained within comfort } \\
\text { zone after heating or cooling equipment } \\
\text { was shut off. }\end{array}$ \\
\hline & Athientis et al. [56] & $\begin{array}{l}\text { EXP } \\
\text { NUM }\end{array}$ & Cooling & $\begin{array}{l}20.8^{\circ} \mathrm{C} \text { Melting } \\
16{ }^{\circ} \mathrm{C} \text { Solidification }\end{array}$ & $25 w t \%$ butyl stearate & $\begin{array}{l}\text { - Room air temperature was reduced by } 4{ }^{\circ} \mathrm{C} \text { using } \\
\text { PCM wallboard under summer conditions. } \\
\text { - Significant reduction of room mean radiant } \\
\text { temperature due to absorption of solar gains } \\
\text { in the PCM board. } \\
\text { - Overheating in buildings was reduced. }\end{array}$ \\
\hline & Shilei et al. $[57,58]$ & EXP & $\begin{array}{l}\text { Heating } \\
\text { Cooling }\end{array}$ & $\begin{array}{l}18.5^{\circ} \mathrm{C} \text { Melting } \\
18.5^{\circ} \mathrm{C} \\
\text { Solidification }\end{array}$ & $\begin{array}{l}26 w t \% \text { fatty acid } \\
\text { mixture }\end{array}$ & $\begin{array}{l}\text { - Low indoor air fluctuation. } \\
\text { - Reduce the heat-transfer to outdoor air } \\
\text { (heating). } \\
\text { - Decrease the cold load of air conditioning } \\
\text { (cooling) }\end{array}$ \\
\hline & Rudd [59] & EXP & - & $24.9^{\circ} \mathrm{C}$ & $25 w t \%$ fatty acid & $\begin{array}{l}\text { - DSC testing showed the same results obtained in } \\
\text { experiments done at room scale. }\end{array}$ \\
\hline & Voelker et al. [60] & $\begin{array}{l}\text { EXP } \\
\text { NUM }\end{array}$ & Cooling & $\begin{array}{l}26.5^{\circ} \mathrm{C} \text { Melting } \\
28^{\circ} \mathrm{C} \text { Solidification } \\
27^{\circ} \mathrm{C} \text { Melting } \\
25.5^{\circ} \mathrm{C} \\
\text { Solidification }\end{array}$ & $\begin{array}{l}\text { Microencapsulated } \\
\text { paraffin } \\
\text { Salt hydrate }\end{array}$ & $\begin{array}{l}\text { - Maximum temperature reduction of PCM gypsum } \\
\text { of up to } 4{ }^{\circ} \mathrm{C} \text { compared to conventional gypsum. } \\
\text { - PCM loses their heat storage capacity after a few } \\
\text { consecutive hot days, if they cannot be } \\
\text { discharged overnight. }\end{array}$ \\
\hline & Liu and Awbi [61] & EXP & Cooling & $21.7^{\circ} \mathrm{C}$ & $\begin{array}{l}60 \% \text { microencapsulated } \\
\text { paraffin }\end{array}$ & $\begin{array}{l}\text { - The heat flux capacity of PCM wall is almost } \\
\text { twice as large as that for an ordinary wall. }\end{array}$ \\
\hline & $\begin{array}{l}\text { Kuznik and } \\
\text { Virgone }[62,63]\end{array}$ & EXP & $\begin{array}{l}\text { Heating } \\
\text { Cooling }\end{array}$ & $\begin{array}{l}13.6^{\circ} \mathrm{C} \text { Melting } \\
23.5^{\circ} \mathrm{C} \\
\text { Solidification }\end{array}$ & $\begin{array}{l}60 \% \text { microencapsulated } \\
\text { paraffin }\end{array}$ & $\begin{array}{l}\text { - PCM in the walls strongly reduces the } \\
\text { overheating effect. } \\
\text { - Wall surface temperature is lower when } \\
\text { using PCM wallboard. } \\
\text { - Natural convection mixing of the air is also } \\
\text { enhanced by PCM material, avoiding } \\
\text { uncomfortable thermal stratifications. }\end{array}$ \\
\hline & Oliver [64] & EXP & - & $26^{\circ} \mathrm{C}$ & $\begin{array}{l}\text { 45wt\% microencapsulated } \\
\text { paraffin }\end{array}$ & $\begin{array}{l}\text { - PCM gypsum board was reported to store } 5 \\
\text { times more energy per unit mass than a } \\
\text { conventional one, the same amount of } \\
\text { energy than a brick wall of } 12 \mathrm{~cm} \text { thick. }\end{array}$ \\
\hline & Heim and Clarke [65] & NUM & - & - & - & $\begin{array}{l}\text { - Solar energy stored in the PCM-gypsum } \\
\text { panels can reduce the heating energy demand } \\
\text { by up to } 90 \% \text { at times during the heating season. }\end{array}$ \\
\hline & Mandilaras et al. [66] & EXP & Cooling & $23^{\circ} \mathrm{C}-26^{\circ} \mathrm{C}$ & $\begin{array}{l}\text { Microencapsulated } \\
\text { paraffin mixture }\end{array}$ & $\begin{array}{l}\text { - PCM was not working in July and August in } \\
\text { Greece climate, since temperatures recorded } \\
\text { were above the solidification } \\
\text { point making not possible the solidification. }\end{array}$ \\
\hline & Zhou et al. [67] & NUM & Heating & - & - & $\begin{array}{l}\text { - PCM optimal melting temperature of } 21^{\circ} \mathrm{C} \\
\text { in Beijing, China. } \\
\text { - Shape-stabilized PCM plates are proved to } \\
\text { have a faster thermal response than } \\
\text { PCM-gypsum }\end{array}$ \\
\hline & Neeper [68] & NUM & - & - & $\begin{array}{l}\text { 10wt\% PCM } \\
\text { 20wt\% PCM } \\
\text { Paraffin and fatty acids }\end{array}$ & $\begin{array}{l}\text { - PCM wallboard has little effect on the net } \\
\text { heat conducted unless the thermal storage } \\
\text { affects the average room temperature. }\end{array}$ \\
\hline & $\begin{array}{l}\text { Stovall and } \\
\text { Tomlinson [69] }\end{array}$ & NUM & $\begin{array}{l}\text { Heating } \\
\text { Cooling }\end{array}$ & - & $30 w t \%$ paraffin & $\begin{array}{l}\text { - PCM-wallboard is ineffective in modifying the } \\
\text { comfort level, but can provide significant } \\
\text { load management relief. }\end{array}$ \\
\hline & Peippo et al. [70] & NUM & Heating & - & - & $\begin{array}{l}\text { - It was shown energy savings of } 10-15 \% \text { could } \\
\text { be made if the PCM wall was positioned in a } \\
\text { direct gain room in a } \\
\text { residential dwelling. } \\
\text { - The optimal thickness of the PCM was } \\
\text { determined between } 10 \mathrm{~mm} \text { and } 15 \mathrm{~mm} \text {. }\end{array}$ \\
\hline & Kuznik et al. [71,72] & EXP & Cooling & $\begin{array}{l}13.6^{\circ} \mathrm{C} \text { Melting } \\
23.5^{\circ} \mathrm{C} \\
\text { Solidification }\end{array}$ & $\begin{array}{l}60 \% \text { microencapsulated } \\
\text { paraffin }\end{array}$ & $\begin{array}{l}\text { - PCM wallboard is really efficient if the air } \\
\text { temperature is varying in the melting and } \\
\text { freezing temperatures. } \\
\text { - Available storage energy in } 5 \mathrm{~mm} \text { of PCM } \\
\text { wallboard is twice higher with PCM material } \\
\text { and corresponds to an } \\
\text { equivalent concrete layer of about } 8 \mathrm{~cm} \text {. }\end{array}$ \\
\hline & Colclough et al. [73] & NUM & $\begin{array}{l}\text { Heating } \\
\text { Cooling }\end{array}$ & $23^{\circ} \mathrm{C}-26^{\circ} \mathrm{C}$ & - & $\begin{array}{l}\text { - Wallboards modulate temperature profile of } \\
\text { internal space with best results in } \\
\text { Mediterranean countries during summer. } \\
\text { - While in Northern Ireland climate wallboard } \\
\text { modulated night time temperatures, decreasing } \\
\text { the temperature drop overnight, } \\
\text { and hence reducing the total heating demand. }\end{array}$ \\
\hline
\end{tabular}


Table 4 (continued)

\begin{tabular}{|c|c|c|c|c|c|c|}
\hline & Reference & Type & Application & $\begin{array}{l}\text { Phase change } \\
\text { temperature }\end{array}$ & PCM quantity & Performance \\
\hline \multirow[t]{4}{*}{ Sandwich panel } & Carbonari et al. [74] & $\begin{array}{l}\text { EXP } \\
\text { NUM }\end{array}$ & Cooling & $32{ }^{\circ} \mathrm{C}$ & Eutectic salts & $\begin{array}{l}\text { - An air layer between the PCM and external } \\
\text { metal finishing layer is capable of improving } \\
\text { the performance of sandwich } \\
\text { panels containing PCM. }\end{array}$ \\
\hline & Medina et al. [75] & EXP & Cooling & $\begin{array}{l}32.5^{\circ} \mathrm{C} \text { Melting } \\
25{ }^{\circ} \mathrm{C} \text { Solidification }\end{array}$ & $\begin{array}{l}10 \% \text { and } 20 \% \text { based } \\
\text { on indoor sheathing } \\
\text { weight of } \\
\text { paraffin-based }\end{array}$ & $\begin{array}{l}\text { - PCM can lead to a significantly reduced } \\
\text { wall heat fluxes during peak times. } \\
\text { - Average reductions in daily heat transfer across } \\
\text { the PCM-panel were } 33 \% \text { and } 38 \% \text { for } \\
\text { concentrations of } 10 \% \text { and } 20 \% \text { PCM, respectively. } \\
\text { - PCM-panel would perform better in climates } \\
\text { where there is a large temperature swing } \\
\text { between day and night. }\end{array}$ \\
\hline & $\begin{array}{l}\text { Konuklu and } \\
\text { Paksoy [76] }\end{array}$ & EXP & $\begin{array}{l}\text { Heating } \\
\text { Cooling }\end{array}$ & $26^{\circ} \mathrm{C}$ and $23^{\circ} \mathrm{C}$ & $\begin{array}{l}\text { Microencapsulated } \\
\text { powdered paraffin }\end{array}$ & $\begin{array}{l}\text { - A reduction on the cooling load of } 7 \% \text { was } \\
\text { achieved with the PCM sandwich panel, } \\
\text { while in winter the heating load was } \\
\text { decreased by } 17 \% \text {. }\end{array}$ \\
\hline & Castellón et al. [77] & EXP & - & $26^{\circ} \mathrm{C}$ & $\begin{array}{l}\text { 8wt\% microencapsulated } \\
\text { paraffin mixture }\end{array}$ & $\begin{array}{l}\text { - Thermal inertia is increased in cases where } \\
\text { the PCM is added to during the manufacturing } \\
\text { process of the sandwich panel. } \\
\text { - While mixing PCM with the polyurethane } \\
\text { PCM effect is overlapped by a possible } \\
\text { increase in thermal conductivity. }\end{array}$ \\
\hline \multirow[t]{10}{*}{$\begin{array}{l}\text { MACRO- } \\
\text { ENCAPSULATED }\end{array}$} & Castell et al. [78] & EXP & Cooling & $\begin{array}{l}28^{\circ} \mathrm{C} \text { and } 26^{\circ} \mathrm{C} \\
\text { Melting } \\
26^{\circ} \mathrm{C} \text { and } 25^{\circ} \mathrm{C} \\
\text { Solidification }\end{array}$ & $\begin{array}{l}\text { Paraffin and } \\
\text { salt hydrates }\end{array}$ & $\begin{array}{l}\text { - Energy consumption of the cooling equipment } \\
\text { was reduced about 15\% in the house-like cubicles } \\
\text { with PCM compared to the ones without PCM. }\end{array}$ \\
\hline & Zhang et al. [80] & EXP & $\begin{array}{l}\text { Heating } \\
\text { Cooling }\end{array}$ & $20^{\circ} \mathrm{C}-30^{\circ} \mathrm{C}$ & $\begin{array}{l}10 w t \%-20 w t \% \\
\text { Paraffin based }\end{array}$ & $\begin{array}{l}\text { - Peak heat fluxes through the PCM frame wall } \\
\text { were substantially reduced when compared } \\
\text { to those through the typical wall. } \\
\text { - Space cooling load was reduced from } 8.6 \text { to } 10.8 \% \\
\text { for the } 10 \text { and } 20 \% \text { concentrations, respectively. }\end{array}$ \\
\hline & Ismail and Castro [81] & $\begin{array}{l}\text { EXP } \\
\text { NUM }\end{array}$ & Cooling & $23{ }^{\circ} \mathrm{C}-26^{\circ} \mathrm{C}$ & $\begin{array}{l}\text { A mixture of two } \\
\text { commercial grades } \\
\text { of glycol }\end{array}$ & $\begin{array}{l}\text { - Results showed the effectiveness of } \\
\text { PCM-enhanced walls in maintaining } \\
\text { constant and stable indoor air } \\
\text { temperatures and proved the potential for } \\
\text { load reduction and load shifting. }\end{array}$ \\
\hline & $\begin{array}{l}\text { Pasupathy and } \\
\text { Velraj [82] }\end{array}$ & NUM & Cooling & $32.8^{\circ} \mathrm{C}$ & Salt hydrate & $\begin{array}{l}\text { - The double layer of PCM incorporated in the roof } \\
\text { reduced the indoor air temperature fluctuations. }\end{array}$ \\
\hline & Alawadhi [83] & NUM & Cooling & $\begin{array}{l}27{ }^{\circ} \mathrm{C}, 37^{\circ} \mathrm{C} \\
\text { and } 47^{\circ} \mathrm{C}\end{array}$ & 3 type of paraffin & $\begin{array}{l}\text { - Best configuration is PCM location in the } \\
\text { centreline of the brick. } \\
\text { - A reduction of the heat flux up to } 24.2 \% \\
\text { is registered. }\end{array}$ \\
\hline & $\begin{array}{l}\text { de Gracia et al. [84] } \\
\text { and Castell et al. [85] }\end{array}$ & EXP & Cooling & $\begin{array}{l}28^{\circ} \mathrm{C} \text { and } 26^{\circ} \mathrm{C} \\
\text { Melting } \\
26{ }^{\circ} \mathrm{C} \text { and } 25{ }^{\circ} \mathrm{C} \\
\text { Solidification }\end{array}$ & $\begin{array}{l}\text { Paraffin and } \\
\text { salt hydrates }\end{array}$ & $\begin{array}{l}\text { - LCA analysis showed that PCM incorporation } \\
\text { did not significantly affect the environmental } \\
\text { impact of a building, for a life span of } 50 \text { years. } \\
\text { - Salt hydrates had less environmental impact } \\
\text { than paraffin. }\end{array}$ \\
\hline & $\begin{array}{l}\text { Silva et al. [86] and } \\
\text { Vicente and Silva [87] }\end{array}$ & EXP & Cooling & $18{ }^{\circ} \mathrm{C}$ & Paraffin & $\begin{array}{l}\text { - Reduction of the temperature swing from } 10{ }^{\circ} \mathrm{C} \\
\text { in the reference to } 5{ }^{\circ} \mathrm{C} \text { with PCM and an } \\
\text { increase in the time } \\
\text { lag of } 3 \mathrm{~h} \text { with PCM. } \\
\text { - Combination of PCM and external insulation } \\
\text { ( } 10 \mathrm{~cm} \text { XPS) resulted in } 80 \% \text { reduction of } \\
\text { thermal amplitude. }\end{array}$ \\
\hline & $\begin{array}{l}\text { Allawadhi and } \\
\text { Alqallaf [88] }\end{array}$ & NUM & Cooling & $\begin{array}{l}27{ }^{\circ} \mathrm{C}, 37^{\circ} \mathrm{C} \\
\text { and } 47{ }^{\circ} \mathrm{C}\end{array}$ & 3 type of paraffin & $\begin{array}{l}\text { - Different PCM geometries were studied when } \\
\text { including in concrete roof component. } \\
\text { - Conical geometry achieved the best thermal } \\
\text { effectiveness reducing heat flux up to } 39 \% \text {. }\end{array}$ \\
\hline & Cerón et al. $[89,90]$ & EXP & Cooling & $\begin{array}{l}20{ }^{\circ} \mathrm{C} \text { Melting } \\
13.5^{\circ} \mathrm{C} \\
\text { Solidification }\end{array}$ & $4.8 \mathrm{~L}$ paraffin mixture & $\begin{array}{l}\text { - The surface temperature of pavement with PCM } \\
\text { installed in a test cell showed more stabilized } \\
\text { values than those without. }\end{array}$ \\
\hline & Kong et al. [91] & EXP & Cooling & $30.2^{\circ} \mathrm{C}$ and $26.5^{\circ} \mathrm{C}$ & $\begin{array}{l}\text { Two different } \\
\text { mixtures of } \\
\text { fatty acids }\end{array}$ & $\begin{array}{l}\text { - Peak temperature decrease, reduction of } \\
\text { temperature fluctuations, and thermal } \\
\text { inertia increase especially with PCM in } \\
\text { the inner walls surface. }\end{array}$ \\
\hline $\begin{array}{l}\text { Micro-encapsulated } \\
\text { in clayboard }\end{array}$ & Colclough [92] & EXP & - & $23{ }^{\circ} \mathrm{C}$ & $30 \%$ by weight & $\begin{array}{l}\text { - PCM-clayboard modulated the internal } \\
\text { temperature of the test cell. } \\
\text { - Rupturing of the PCM microcapsules }\end{array}$ \\
\hline
\end{tabular}

PCM gap filling although the solar heating gain coefficient and shading coefficient were unaffected. On comparing these values with conventional air filled double glazing, all three values were higher for glass panels filled with PCM.

\section{Conclusions}

Nowadays 30\% of global energy is consumed in buildings, energy trends shows that decreasing the energy demand of buildings 


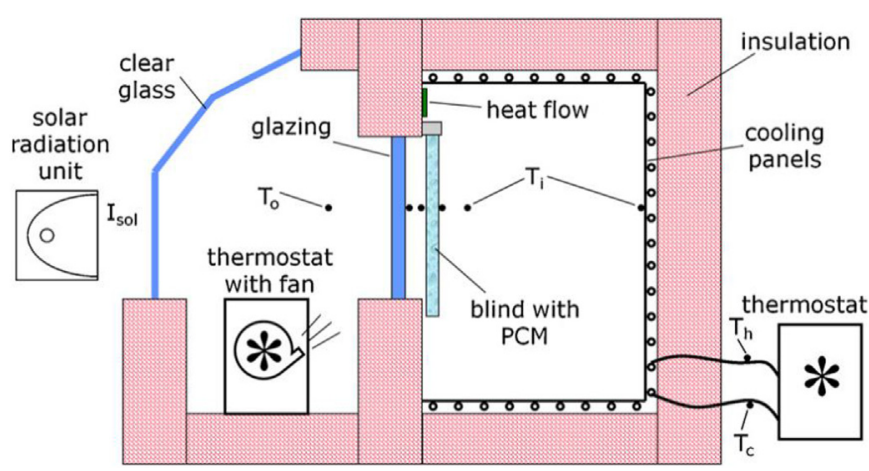

Fig. 31. Sun protection testing chamber [93].

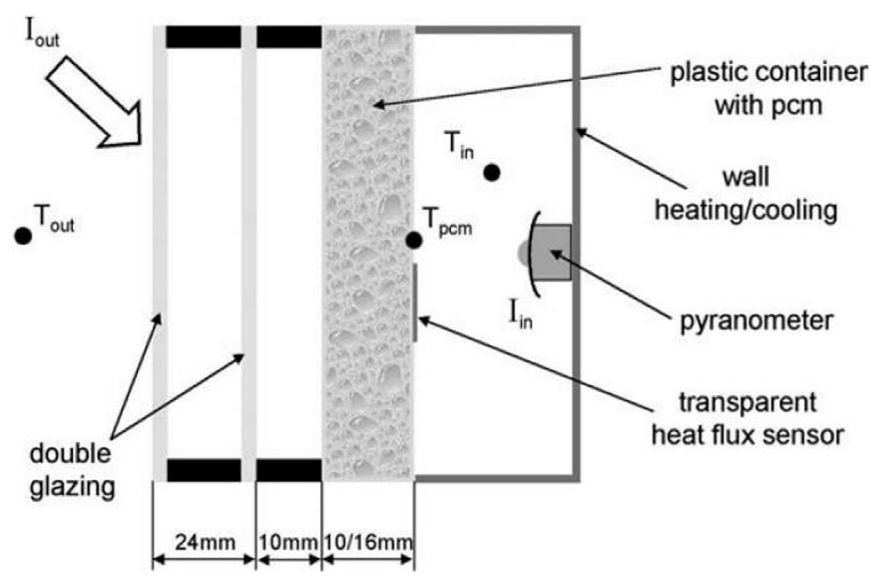

Fig. 32. Experimental set-up of outdoor test facility [94].

is a huge necessity. Thermal energy storage is one of the highlighted technologies to achieve this aim, and its integration in buildings is of much interest, to achieve a better final user acceptance of the technology.

Thermal energy storage has been applied in buildings envelopes for many years, using sensible heat storage in traditional building materials such as stone, earth, brick and concrete. Many studies have compared thermal inertia construction systems against lightweight systems such as wooden frame having better thermal performance due to the higher thermal mass. However, depending on the climate conditions, thermal mass has a low influence on the heating and cooling demands of a building. In spite of this, solar walls were designed to increase the potential of the sensible heat storage of the high thermal mass envelopes. Even though, the standard solar wall registered energetic benefits, many researchers have modified the original operation adding mechanical or natural ventilation.

Latent heat storage is known as a potential technology to reduce energy demand in buildings. Phase change materials have been incorporated in buildings envelope as a passive system inside building materials (concrete, plaster) or as a new layer in the construction system. Several methods of PCM incorporation inside the material are reviewed in this paper concluding that direct incorporation, immersion and vacuum impregnation methods could have leakage problems and possible incompatibility with some building materials mainly with concrete. On the other hand, PCM encapsulation methods are relatively easy to implement in construction materials although there is also a limit in the quantity of PCM when microcapsules are added. Moreover, the effect of adding PCM inside the building material, regardless the method used, should be taken into account, because material properties are demonstrated to be affected such as mechanical properties and durability among others.

Several experimental studies presented in this paper were classified depending on where the PCM is included and the method used, whether inside the material or as a new layer in a construction system. A large amount of literature was found on PCM addition in plasterboard mainly used as a passive cooling solution to reduce the overheating effect. Immersion and microencapsulation are the methods most commonly used, specially the second microencapsulation due to its ease of incorporation. The amount of PCM added to the wallboard around $25 \%$ in weight or less had a low effect on the internal ambient conditions and most of the times are not economic feasibility. On the other hand, in many studies the commercial product Energain ${ }^{\circledR}$ which contains $60 \%$ of PCM registered significant temperature reductions and an increase of the heat convection coefficient.

Few studies tested PCM inclusion in sandwich panels as an external protection from the summer conditions. In these applications, phase change temperature is higher than the comfort temperatures oscillating from $24^{\circ} \mathrm{C}$ to $32^{\circ} \mathrm{C}$. The incorporation in different parts of the panel were studied, metals sheet, metal pipes, and mixed in the polyurethane, being the last option the best due to its uniformity.

Macro-encapsulated PCM studies for building applications are growing in interest, as their encapsulation, eliminate leakage problems, incompatibility with construction materials, and do not affect materials properties. Several ways of including macroencapsulated PCM in building envelopes were presented such as inside hollows of bricks, under the floor lining, or even inside the ceiling component. Some of the applications were designed to be actively charged through solar radiation for heating purposes, while others act as a passive cooling system absorbing heat loads. In

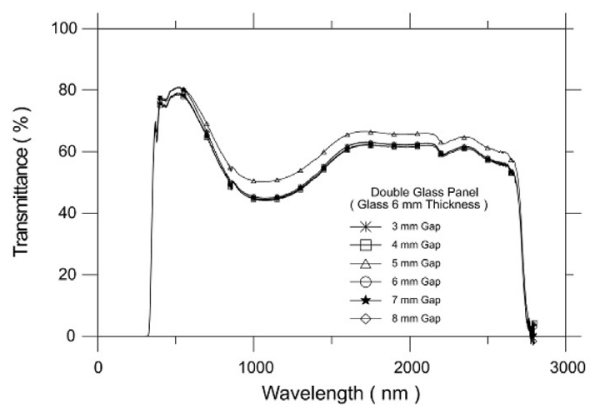

(a)

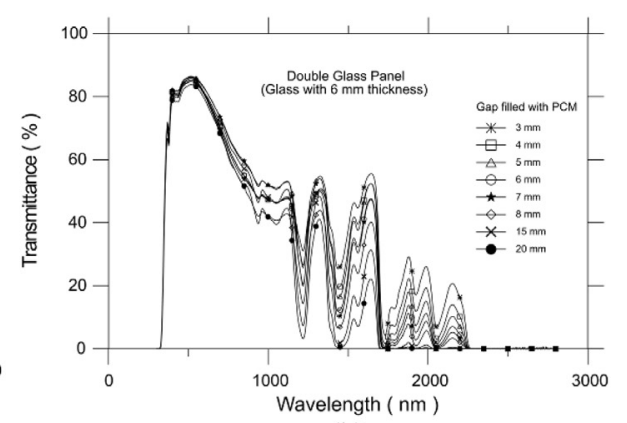

(b)

Fig. 33. Transmittance of double glass panel for different gap values filled with (a) air and (b) PCM [96]. 
general terms, the incorporation of phase change materials into the construction elements of a building is demonstrated to improve the stability of the internal temperatures by the thermal inertia effect.

\section{Acknowledgements}

The work was carried out under the framework of the COST Action BISTS TU1205. The research leading to these results has received funding from the European Union's Seventh Framework Programme (FP7/2007-2013) under grant agreement $n^{\circ}$ PIRSESGA-2013-610692 (INNOSTORAGE). The authors from the University of Lleida would like to thank the Catalan Government for the quality accreditation given to their research group (2014 SGR 123). Alvaro de Gracia would like to thank Education Ministry of Chile for Grant PMI ANT1201.

\section{References}

[1] D. Urge-Vorsatz, L.F. Cabeza, S. Serrano, C. Barreneche, K. Petrichenko, Heating and cooling energy trends and drivers in buildings, Renew. Sustain. Energy Rev. 41 (2015) 85-98.

[2] L. Navarro, A. de Gracia, S. Colclough, S. McCormack, P. Griffiths, L.F. Cabeza, Thermal energy storage in building integrated thermal systems: a review. Part 1. Integration as active system, Renew. Energy (2015) (in press).

[3] H. Mehling, L.F. Cabeza, Heat and Cold Storage with PCM: an up to Date Introduction into Basics and Applications, Springer, Heidelberg, Berlin, 2008.

[4] J. Kosny, T. Petrie, D. Gawin, P. Childs, A. Desjarlais, J. Christian, Thermal Mass - Energy Savings Potential in Residential Buildings, Buildings Technology Center, ORNL, October 2014. Available in: http://web.ornl.gov/sci/ roofs+walls/research/detailed_papers/thermal/index.html.

[5] A.R. Rempel, A.W. Rempel, Rocks, clays, water, and salts: highly durable, infinitely rechargeable, eminently controllable thermal batteries for buildings, Geosciences 3 (1) (2013) 63-101.

[6] T. Basaran, Thermal analysis of the domed vernacular houses of Harran, Turkey, Indoor Built Environ. 20 (5) (2011) 543-554.

[7] D.M. Ogoli, Predicting indoor temperatures in closed buildings with high thermal mass, Energy Build. 35 (9) (2003) 851-862.

[8] P. Taylor, R.J. Fuller, M.B. Luther, Energy use and thermal comfort in a rammed earth office building, Energy Build. 40 (5) (2008) 793-800.

[9] K. Ip, A. Miller, Thermal behaviour of an earth-sheltered autonomous building - the Brighton Earthship, Renew. Energy 34 (9) (2009) 2037-2043.

[10] L. Zhu, R. Hurt, D. Correia, R. Boehm, Detailed energy saving performance analyses on thermal mass walls demonstrated in a zero energy house, Energy Build. 41 (3) (2009) 303-310.

[11] A. Dodoo, L. Gustavsson, R. Sathre, Effect of thermal mass on life cycle primary energy balances of a concrete- and a wood-frame building, Appl. Energy 92 (2012) 462-472.

[12] S. Ünalan, E. Özrahat, The concrete columns as a sensible thermal energy storage medium and a heater, Heat Mass Transf. 50 (8) (2014) 1037-1052.

[13] A. de Gracia, A. Castell, M. Medrano, L.F. Cabeza, Dynamic thermal performance of alveolar brick construction system, Energy Convers. Manag. 52 (7) (2011) 2495-2500.

[14] O. Saadatian, K. Sopian, C.H. Lim, N. Asim, M.Y. Sulaiman, Trombe walls: a review of opportunities and challenges in research and development, Renew. Sustain. Energy Rev. 16 (8) (2012) 6340-6351.

[15] F. Stazi, A. Mastrucci, C. di Perna, The behaviour of solar walls in residential buildings with different insulation levels: an experimental and numerical study, Energy Build. 47 (2012) 217-229.

[16] A. Briga-Sá, A. Martins, J. Boaventura-Cunha, J.C. Lanzinha, A. Paiva, Energy performance of Trombe walls: adaptation of ISO 13790:2008(E) to the Portuguese reality, Energy Build. 74 (2014) 111-119.

[17] J. Llovera, X. Potau, M. Medrano, L.F. Cabeza, Design and performance of energy-efficient solar residential house in Andorra, Appl. Energy 88 (2010) $1343-1353$.

[18] G. Gan, Simulation of buoyancy-induced flow in open cavities for natural ventilation, Energy Build. 38 (5) (2006) 410-420.

[19] M.F. Hordeski, Dictionary of Energy Efficiency Technologies, Fairmont Press, Liburn, Georgia (USA), 2004.

[20] Q. Yang, L.H. Zhu, J.J. He, Z.F. Yan, R. Ren, Integrating passive cooling and solar techniques into the existing building in South China, Adv. Mater. Res. 37 (2011) 368-373.

[21] Adams S, Becker M, Krauss D, Gilman CM. Not a dry subject: optimizing water Trombe wall. SOLAR 2010 Conference. Colorado, USA: Society ASE, editor.

[22] H.L. Simmons, Olin's Construction: Principles, Materials, and Methods, John Wiley \&Sons, New Jersey, USA, 2011.

[23] S.A. Memon, Phase change materials integrated in building walls: a state of the art review, Renew. Sustain. Energy Rev. 31 (2014) 870-906.

[24] D. Feldman, D. Banu, D. Hawes, E. Ghanbari, Obtaining an energy storing building material by direct incorporation of an organic phase change materia in gypsum wallboard, Sol. Energy Mater. 22 (1991) 231-242.

25] N. Soares, J.J. Costa, A.R. Gaspar, P. Santos, Review of passive PCM latent heat thermal energy storage systems towards buildings' energy efficiency, Energy and Build. 59 (2013) 82-103.

[26] T.C. Ling, C.S. Poon, Use of phase change materials for thermal energy storage in concrete: an overview, Constr. Build. Mater. 46 (2013) 55-62.

[27] D.W. Hawes, D. Banu, D. Feldman, Latent heat storage in concrete, Sol. Energy Mater. 19 (1989) 335-348.

[28] T. Lee, D.W. Hawes, D. Banu, D. Feldman, Control aspects of latent heat storage and recovery in concrete, Sol. Energy Mater. Sol. Cells 62 (3) (2000) 217-237.

[29] D.P. Bentz, R. Turpin, Potential applications of phase change materials in concrete technology, Cem. Concr. Compos. 29 (7) (2007) 527-532.

[30] D. Bajare, J. Kazjonovs, A. KorjakinsProceedings of the 8th International Scientific and Practical Conference, Rēzekne, RA Izdevniecíba, The therma characteristics of gypsum boards with phase change materials (PCM), Environ., Technol. Resour. 2 (2011) 132-138.

[31] D. Zhang, J. Zhou, K. Wu, Study of phase-changing energy storage composite material and its power peak regulation function, East China Electr. Power 31 (2003) 27-30.

[32] C. Barreneche, A. de Gracia, S. Serrano, M.E. Navarro, A.M. Borreguero, A.I. Fernández, M. Carmona, J.F. Rodríguez, L.F. Cabeza, Comparison of three different devices available in Spain to test thermal properties of building materials including phase change materials, Appl. Energy 109 (2013) 421-427.

[33] D. Zhang, K. Wu, Z. Li, Tunning effect of porous media's structure on the phase changing behaviour of organic phase changing matters, J. Tongji Univ. 32 (2004) 1163-1167.

[34] D. Zhang, J. Zhou, K. Wu, Z. Li, Granular phase changing composites for thermal energy storage 78 (3) (2005) 471-480.

[35] A. Felix Regin, S.C. Solanki, J.S. Saini, An analysis of a packed bed latent heat thermal energy storage system using PCM capsules: numerical investigation, Renew. Energy 34 (7) (2009) 1765-1773.

[36] L.F. Cabeza, A. Castell, C. Barreneche, A. de Gracia, A.I. Fernandez, Materials used as PCM in thermal energy storage in buildings: a review, Renew. Sustain. Energy Rev. 15 (3) (2011) 1675-1695.

[37] A.M. Khudair, M.M. Farid, A review on energy conservation in building applications with thermal storage by latent heat using phase change materials Energy Convers. Manag. 45 (2) (2004) 263-275.

[38] S.K. Park, J.H. Jay Kim, J.W. Nam, D.P. Hung, J.K. Kim, Development of antifungal mortar and concrete using zeolite and zeocarbon microcapsules, Cem. Concr. Compos. 31 (2009) 447-453.

[39] M. Hunger, A.G. Entrop, I. Mandilaras, H.J.H. Brouwers, M. Founti, The behavior of self-compacting concrete containing micro-encapsulated phase change materials, Cem. Concr. Compos. 31 (10) (2009) 731-743.

[40] M. Fenollera, J.L. Míguez, I. Goicoechea, J. Lorenzo, M.A. Álvarez, The influence of phase change materials on the properties of self-compacting concrete Materials 6 (8) (2013) 3530-3546.

[41] Y.P. Zhang, K.P. Lin, R. Yang, H.F. Di, Y. Jiang, Preparation, thermal performance and application of shape-stabilized PCM in energy efficient buildings, Energy Build. 38 (2006) 1262-1269.

[42] A. Sarı, Form-stable paraffin/high density polyethylene composites as solid-liquid phase change material for thermal energy storage: preparation and thermal properties, Energy Convers. Manag. 45 (2004) 2033-2042.

[43] A. Karaipekli, A. Sarı, Capric-myristic acid/vermiculite composite as formstable phase change material for thermal energy storage, Sol. Energy 83 (2009) 323-332.

[44] S.A. Memon, T.Y. Lo, H. Cui, S. Barbhuiya, Preparation, characterization and thermal properties of dodecanol/cement as novel form-stable composite phase change material, Energy Build. 66 (2013) 697-705.

[45] S.A. Memon, T.Y. Lo, S.A. Barbhuiya, W. Xu, Development of form-stable composite phase change material by incorporation of dodecylalcohol into ground granulated blast furnace slag, Energy Build. 62 (2013) 360-367.

[46] M.Z. Pomianowski, P. Heiselberg, R.L. Jensen, Experimental investigation of thermal conductivity of concrete containing micro encapsulated phase change materials, in: 7th International Symposium on Heating, Ventilating and Air Conditioning - Proceedings of ISHVAC, vol. 1, 2011, pp. 185-191.

[47] A. Eddhahak-Ouni, S. Drissi, J. Colin, J. Neji, S. Care, Experimental and multiscale analysis of the thermal properties of Portland cement concretes embedded with microencapsulated phase change materials (PCMs), Build Environ. 45 (8) (2010) 1762-1768.

[48] Y.F. Li, D. Zhang, Thermal conductivity anisotropy of expanded grphite/LiCl $\mathrm{NaCl}$ phase change material, J. Funct. Mater. 44 (16) (2013) 1409-1415.

[49] D.I. Kolaitis, E.K. Asimakopoulou, M.A. Founti, Gypsum plasterboards enhanced with phase change materials: a fire safety assessment using experimental and computational techniques, 2013. MATEC Web of Conferences, 9, Article number 06002.

[50] L.F. Cabeza, C. Castellón, M. Nogués, M. Medrano, R. Leppers, O. Zubillaga, Use of microencapsulated PCM in concrete walls for energy savings, Energy Build 39 (2007) 113-119.

[51] P. Schossig, H.-M. Henning, S. Gschwander, T. Haussmann, Micro-encapsulated phase-change materials integrated into construction materials, Sol. Energy Mater. Sol. Cells 89 (2005) 297-306.

[52] A.V. Sá, M. Azenha, H. De Sousa, A. Samagaio, Thermal enhancement of plastering mortars with phase change materials: experimental and numerical approach, Energy Build. 49 (2012) 16-27. 
[53] A.C. Evers, M.A. Medina, Y. Fang, Evaluation of the thermal performance of frame walls enhanced with paraffin and hydrated salt phase change materials using a dynamic wall simulator, Build. Environ. 45 (2010) 1762-1768.

[54] J. Kosny, E. Kossecka, A. Brzezinski, A. Tleoubaev, D. Yarbrough, Dynamic thermal performance analysis of fiber insulations containing bio-based phase change materials (PCMs), Energy Build. 52 (2012) 122-131.

[55] S. Scalat, D. Banu, D. Hawes, J. Paris, F. Haghighat, D. Feldman, Full scale thermal testing of latent heat storage in wallboard, Sol. Energy Mater. Sol. Cells 44 (1996) 46-61.

[56] A.K. Athienitis, C. Liu, D. Hawes, D. Banu, D. Feldman, Investigation of the thermal performance of a passive solar test-room with wall latent heat storage, Build. Environ. 32 (1997) 405-410.

[57] L. Shilei, Z. Neng, F. Guohui, Impact of phase change wall room on indoor thermal environment in winter, Energy Build. 38 (1) (2006) 18-24.

[58] L. Shilei, F. Guohui, Z. Neng, D. Li, Experimental study and evaluation of latent heat storage in phase change materials wallboards, Energy Build. 39 (10) (2007) 1088-1091.

[59] A.F. Rudd, Phase change material wallboard for distributes thermal storage in buildings, ASHRAE 99 (2) (1993) 339-346.

[60] C. Voelker, O. Kornadt, M. Ostry, Temperature reduction due to the application of phase change materials, Energy Build. 40 (2008) 937-944.

[61] H. Liu, H.B. Awbi, Performance of phase change material boards under natural convection, Build. Environ. 44 (9) (2009) 1788-1793.

[62] F. Kuznik, J. Virgone, Experimental assessment of phase change material for wall building use, Appl. Energy 86 (2009) 2038-2046.

[63] F. Kuznik, J. Virgone, Experimental investigation of wallboard containing phase change material: data for validation of numerical modelling, Energy Build. 41 (2009) 561-570.

[64] A. Oliver, Thermal characterization of gypsum boards with PCM included: thermal energy storage in buildings through latent heat, Energy Build. 48 (2012) 1-7.

[65] D. Heim, J.A. Clarke, Numerical modelling and thermal simulation of PCMgypsum composites with ESP-r, Energy Build. 36 (2004) 795-805.

[66] I. Mandilaras, M. Stamatiadou, D. Katsourinis, G. Zannis, M. Founti, Experimental thermal characterisation of a Mediterranean residential building with PCM gypsum board walls, Build. Environ. 61 (2013) 93-103.

[67] G. Zhou, Y. Zhang, X. Wang, K. Lin, W. Xiao, An assessment of mixed type PCM-gypsum and shape stabilised PCM plates in a building for passive solar heating, Sol. Energy 81 (2007) 1351-1360.

[68] D.A. Neeper, Thermal dynamics of wallboard with latent heat storage, Sol. Energy 68 (2000) 393-403.

[69] T.K. Stovall, J.J. Tomlinson, What are the potential benefits of including latent heat storage in common wall board, Trans. ASME 117 (1995) 318-325.

[70] K. Peippo, P. Kauranen, P.D. Lund, A multi-component pcm wall optimized for passive solar heating, Energy Build. 17 (1991) 259-270.

[71] F. Kuznik, J. Virgone, K. Johannes, In-situ study of thermal comfort enhancement in a renovated building equipped with phase change material wallboard, Renew. Energy 36 (5) (2011) 1458-1462.

[72] F. Kuznik, J. Virgone, J.J. Roux, Energetic efficiency of room wall containing PCM wallboard: a full-scale experimental investigation, Energy Build. 40 (2) (2008) 148-156.

[73] S.M. Colclough, P.W. Griffiths, M.G. Smyth, in: Thermal Energy Storage and the Passive House Standard: How PCM Incorporated into Wallboard Can Aid Thermal Comfort, PLEA Conference, Montreal, Quebec, Canada, 2009.

[74] A. Carbonari, M.D. Grassi, C.D. Perna, P. Principi, Numerical and experimenta analyses of PCM containing sandwich panels for prefabricated walls, Energy Build. 38 (2006) 472-483.
[75] M. Medina, J. King, M. Zhang, On the heat transfer rate reduction of structural insulated panels (SIPs) outfitted with phase change materials (PCMs), Energy 33 (4) (2008) 667-678.

[76] Y. Konuklu, H.O. Paksoy, Phase change material sandwich panels for managing solar gain in buildings, J. Sol. Energy Eng. Trans. ASME 131 (4) (2009) $0410121-0410127$.

[77] C. Castellón, M. Medrano, J. Roca, L.F. Cabeza, M.E. Navarro, A.I. Fernández, A. Lázaro, B. Zalba, Effect of microencapsulated phase change material in sandwich panels, Renew. Energy 35 (2010) 2370-2374.

[78] A. Castell, I. Martorell, M. Medrano, G. Pérez, L.F. Cabeza, Experimental study of using PCM in brick constructive solutions for passive cooling, Energy Build. 42 (2010) 534-540.

[79] Rubitherm. Available in: http://www.rubitherm.de/english/index.htm (October 2014).

[80] M. Zhang, M.A. Medina, J.B. King, Development of a thermally enhanced frame wall with phase change materials for on-peak air conditioning demand reduction and energy savings in residential buildings, Int. J. Energy Res. 29 (2005) 795-809.

[81] K.A.R. Ismail, J.N.C. Castro, PCM thermal insulation in buildings, Int. J. Energy Res. 21 (1997) 1281-1296.

[82] A. Pasupathy, R. Velraj, Effect of double layer phase change material in building roof for year round thermal management, Energy Build. 40 (2008) 193-203.

[83] E.M. Alawadhi, Thermal analysis of a building brick containing phase change material, Energy Build. 40 (2008) 351-357.

[84] A. de Gracia, L. Rincón, A. Castell, M. Jiménez, D. Boer, M. Medrano, L.F. Cabeza, Life Cycle Assessment of the inclusion of phase change materials (PCM) in experimental buildings, Energy Build. 42 (2010) 1517-1523.

[85] A. Castell, K. Menoufi, A. de Gracia, L. Rincón, D. Boer, L.F. Cabeza, Life Cycle Assessment of alveolar brick construction system incorporating phase change materials (PCMs), Appl. Energy 101 (2013) 600-608.

[86] T. Silva, R. Vicente, N. Soares, V. Ferreira, Experimental testing and numerical modelling of masonry wall solution with PCM incorporation: a passive construction solution, Energy Build. 49 (2012) 235-245.

[87] R. Vicente, T. Silva, Brick masonry walls with PCM macrocapsules: an experimental approach, Appl. Therm. Eng. 67 (2014) 24-34.

[88] E.M. Alawadhi, H.J. Alqallaf, Building roof with conical holes containing PCM to reduce the cooling load: numerical study, Energy Convers. Manag. 52 (2011) 2958-2964.

[89] I. Cerón, J. Neila, M. Khayet, Experimental tile with phase change materials (PCM) for building use, Energy Build. 43 (2011) 1869-1874.

[90] Latipat F. Pavimento acondicionador termico para interiores patent 2010, $\mathrm{n}^{0}$ ES2333092.

[91] X. Kong, S. Lu, J. Huang, Z. Cai, S. Wei, Experimental research on the use of phase change materials in perforated brick rooms for cooling storage, Energy Build. 62 (2013) 597-604.

[92] Colclough S, Thermal energy storage applied to the Passivhaus standard in the Irish Climate, (PhD theis), University of Ulster.

[93] H. Weinlaeder, W. Koerner, M. Heidenfelder, Monitoring results of an interior sun protection system with integrated latent heat storage, Energy Build. 43 (9) (2011) 2468-2475.

[94] H. Weinläder, A. Beck, J. Fricke, PCM-facade-panel for daylighting and room heating, Sol. Energy 78 (2) (2005) 177-186.

[95] H. Manz, P.W. Egolf, P. Suter, A. Goetzberger, TIM-PCM external wall system for solar space heating and daylighting, Sol. Energy 61 (6) (1997) 369-379.

[96] K.A.R. Ismail, J.R. Henriquez, Parametric study on composite and PCM glass systems, Energy Convers. Manag. 43 (7) (2002) 973-993. 